\title{
A Review of Gum Hydrocolloid Polyelectrolyte Complexes (PEC) for Biomedical Applications: Their Properties and Drug Delivery Studies
}

\author{
Jindrayani Nyoo Putro ${ }^{1, *(\mathcal{D}}$, Valentino Bervia Lunardi ${ }^{1}\left({ }^{\circledR}\right.$, Felycia Edi Soetaredjo $^{1}$, Maria Yuliana ${ }^{1}$, \\ Shella Permatasari Santoso ${ }^{1}$, I Gede Wenten ${ }^{2,3}$ (D) and Suryadi Ismadji ${ }^{1}$ \\ 1 Department of Chemical Engineering, Widya Mandala Surabaya Catholic University, Kalijudan 37, \\ Surabaya 60114, Indonesia; valentinolunardi70@gmail.com (V.B.L.); felyciae@yahoo.com (F.E.S.); \\ mariayuliana@ukwms.ac.id (M.Y.); shella_p5@yahoo.com (S.P.S.); suryadiismadji@yahoo.com (S.I.) \\ 2 Chemical Engineering Department, Institut Teknologi Bandung, Jalan Ganesa No. 10, \\ Bandung 40132, Indonesia; igw@che.itb.ac.id \\ 3 Research Center for Nanosciences and Nanotechnology, Institute Teknologi Bandung, Jalan Ganesa No. 10, \\ Bandung 40132, Indonesia \\ * Correspondence: jindranyoo@yahoo.com
}

check for

updates

Citation: Putro, J.N.; Lunardi, V.B.; Soetaredjo, F.E.; Yuliana, M.; Santoso, S.P.; Wenten, I.G.; Ismadji, S. A Review of Gum Hydrocolloid Polyelectrolyte Complexes (PEC) for Biomedical Applications: Their Properties and Drug Delivery Studies. Processes 2021, 9, 1796. https:// doi.org/10.3390/pr9101796

Academic Editor: Carla Vitorino

Received: 7 September 2021

Accepted: 8 October 2021

Published: 11 October 2021

Publisher's Note: MDPI stays neutral with regard to jurisdictional claims in published maps and institutional affiliations.

Copyright: (c) 2021 by the authors. Licensee MDPI, Basel, Switzerland. This article is an open access article distributed under the terms and conditions of the Creative Commons Attribution (CC BY) license (https:/ / creativecommons.org/licenses/by/ $4.0 /)$.

\begin{abstract}
The utilization of natural gum polysaccharides as the vehicle for drug delivery systems and other biomedical applications has increased in recent decades. Their biocompatibility, biodegradability, and price are much cheaper than other materials. It is also renewable and available in massive amounts, which are the main reasons for its use in pharmaceutical applications. Gum can be easily functionalized with other natural polymers to enhance their applications. Various aspects of the utilization of natural gums in the forms of polyelectrolyte complexes (PECs) for drug delivery systems are discussed in this review. The application of different mathematical models were used to represent the drug release mechanisms from PECs; these models include a zero-order equation, first-order equation, Higuchi, simplified Higuchi, Korsmeyer-Peppas, and Peppas-Sahlin.
\end{abstract}

Keywords: gum polysaccharides; drug delivery; polyelectrolyte complexes; hydrocolloid

\section{Introduction}

One of the most abundant materials on our planet is polysaccharides; they are cheap, found everywhere, and sustainable. The sources of polysaccharides are plants or animals. Polysaccharides have repetitive structures of monosaccharides and are classified according to their biological functions [1]:

- $\quad$ Plants: cellulose, hemicellulose, starch, pectin, gum.

- Marine algae: alginate, carrageenan, cellulose.

- Crustaceans: chitin.

Polysaccharides are utilized for various applications, and a promising one is a vehicle for drug delivery systems. From 2010 to 2020, many papers focusing on using polysaccharides as a drug delivery were published in various scientific journals. The main reasons for increasing the interest of scientists in this area are its biocompatibility, biodegradable, much cheaper than other materials, renewable, and its availability in massive amounts. Furthermore, different types of polysaccharides and their functionalization also give different behaviors of drug delivery and release.

Polysaccharides as natural polymers have a hydrocolloid behavior, which can form a gel at a specific temperature and/or in the presence of ions. Hydrocolloids are generally applied in food ingredients to control their rheology and structure [2]. The most common hydrocolloid polysaccharides used in the food industry are gum, alginate, carboxymethyl cellulose. Another hydrocolloid material that is frequently used is gelatin, which is derived 
from protein. The awareness of a healthy diet led to high fiber and low-fat food development, making hydrocolloid one of the fastest growing industries. Since it can be used as fat replacers in food, with relatively low concentrations $(<1 \%)$ [3], with this condition, hydrocolloids become an ideal material for drug delivery.

The most commonly studied hydrocolloids as drugs vehicles are plant or seed gums. Many gums have been used in drug delivery systems, such as gum arabic, gum karaya, and gum tragacanth. These three gums have different characteristics; gum arabic can be dissolved at a high concentration of up to $50 \%$ due to its branched structure and low molecular weight. Gum karaya is the least soluble gum; it swells and produces a viscous colloidal solution when dispersed in water; the swelling behavior is due to its acetyl group. Gum tragacanth forms a viscous liquid when dissolved in water, and it is considered acid-resistant gum [4] Besides being used in food formulation, gum can serve as coating and adhesives for pharmaceutical applications [5].

Gum as a carbohydrate can be divided into two parts based on its chemical components: galactomannan and non-galactomannan gum. Galactomannans are polysaccharides consisting of mannose backbone linked to galactose as side chains. Galactomannan solubility in water is influenced by the degree of galactose substitution and mannose/galactose $(\mathrm{M} / \mathrm{G})$ ratio [6]. Non-galactomannan gum has no compound of mannose; instead, it has major compounds of rhamnose-arabinose-galactose or rhamnose-galactose linkage such as gum karaya [7]. Gum can be easily functionalized with other natural polymers to enhance their applications.

Most polysaccharides have an anionic or neutral charge by nature, but chitosan has a positive charge due to its amino functional group. The combination of natural polymer hydrocolloid, gum and chitosan are the general examples of most research studies of polyelectrolyte complexes (PEC) as a pharmaceutical excipient [8]. Several studies investigated the PEC for drug delivery $[9,10]$. PEC occurred when two opposite charge polyelectrolyte mixed simultaneously in an aqueous solution. This phenomenon is also known as the self-assembly process, which indicates an interaction between anion and cation polyelectrolyte driven by the system's entropy [11].

There are three steps in forming a PEC: (a) primary complex formation, (b) secondary complex formation, and (c) intercomplex aggregation, illustrated in Figure 1. When cationic and anionic polymers are mixed, they form a random bond. This step is called primary complex formation. In addition, the rearrangement and correction of bonds will occur as the secondary complex formation. It forms intercomplex fibrils, entangles, or networks [12]. Copolymer PEC consisted of polycation and polyanion, also known as complex coacervate, widely utilized in the pharmaceutical industry due to its characteristics $[13,14]$. This review discusses natural and semi-synthetic polyelectrolyte coacervate complex for the case study of drug loading and release. Apart from that, the polysaccharide is biocompatible in the human body without any adverse effects in vivo, making them suitable as a candidate in the drug delivery field. The focus in this review is limited to gum-related copolymer polysaccharide PEC. The mechanism, structure, drug loading, release ability, and cytotoxicity assay of gum PEC are investigated thoroughly in this review. 


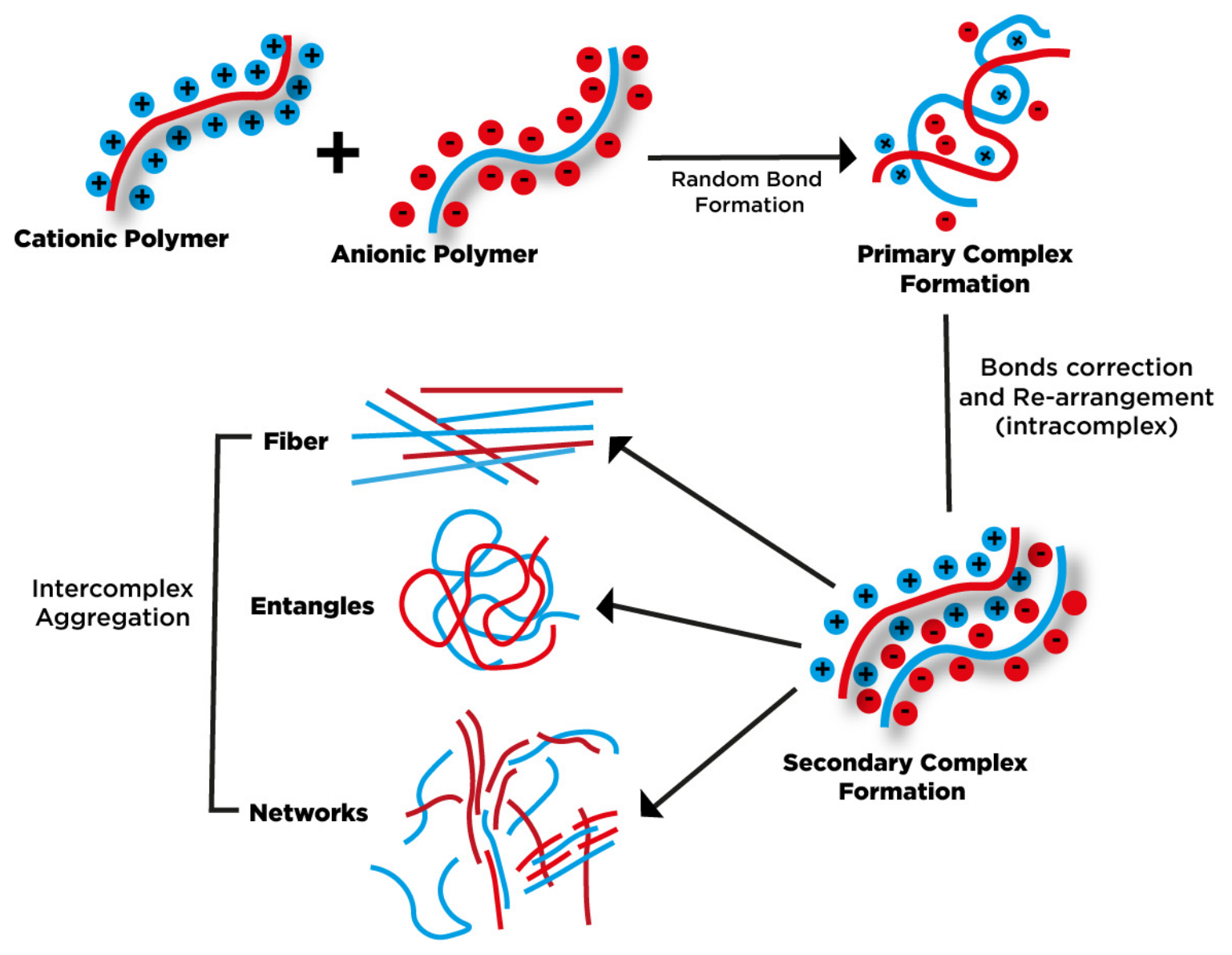

Figure 1. Illustration on the formation of polyelectrolyte complex (adapted from [12]).

\section{The Mechanism of Gum as Hydrocolloid PEC}

Chitosan as a cationic polysaccharide is typically used since it has a positive charge at $\mathrm{pH}$ below 6.5, making it favorable to form PEC with other anionic polymers [15]. The positive and negative charged polymers interact spontaneously and create a colloidal suspension [16]. The structure produced from the electrostatic attractions is influenced by the ratio of cationic and anionic functional groups, which determine the characteristics of PEC, whether it is soluble or insoluble [14]. If the molar ratio of ionic group polyelectrolytes is nonstoichiometric, the PEC is water-soluble [17]. Generally, most synthetic PEC exhibits equal ratio polyelectrolytes of one form micellar aggregates, which has the structure of ladder-like and the scrambled egg model, this type of PEC is insoluble in water [18-20]. Polycation is categorized into two types based on ion charges: pendant-type have charges in the side groups, and integral-type have charges in the chain backbone [21]. Integral polycations provide non-stoichiometry PEC with weak polyanion. In the condition of excess polyanion, there is an interaction of anion with the cation sites of the equimolar complex to create a soluble complex [21]. However, the solubility of PEC produced is also greatly influenced by the branching and the strength of polyelectrolyte, the ionic strength of the environment, and the mixing order of polyelectrolyte components [22,23]. Simultaneous mixing of components has a higher probability of yielding stoichiometric PECs [23].

The formation of PECs is affected by $\mathrm{pH}$ and the ratio of polymers. Several studies investigating the effect of parameters of gum copolymer PEC are summarized in Table 1. As observed in Table 1, the most investigated cationic polymer for studying polyelectrolyte complex in the last ten years is chitosan. Based on the existing data, three parameters can be summed up to the affecting PEC produced in this study. 
Table 1. The parameters used in the preparation of gum-based PECs.

\begin{tabular}{|c|c|c|}
\hline \multicolumn{2}{|c|}{ Natural Polymers } & \multirow[t]{2}{*}{ Parameters } \\
\hline Anionic & Cationic & \\
\hline Gellan gum $(\mathrm{G})$ & Chitosan (C) & $(\% w / v)$ ratio G:C of $(1.5,1.75,2): 1$, acid and alkaline condition [24] \\
\hline Xanthan gum $(X)$ & Chitosan & $\%$ weight ratio $\mathrm{X}: \mathrm{C}=(2-10): 0.5$, spray dried and freeze dried [26] \\
\hline Carboxymethylated cashew gum & Chitosan & $\mathrm{pH} 4$, ionic strength 0.05 , molar charge ratio $\mathrm{n}^{+} / \mathrm{n}^{-}: 0.1$ to 20 [27] \\
\hline Gellan gum & \multirow{2}{*}{ Acrylic ion exchange resin } & \multirow{2}{*}{$\begin{array}{l}\text { Weight ratio polyanion solution:acrylic ion exchange resin }=5: 5, \mathrm{pH} \\
\qquad 5.5,25^{\circ} \mathrm{C}, 24 \mathrm{~h}[28]\end{array}$} \\
\hline Xanthan gum & & \\
\hline Gellan gum & Chitosan & $(\% w / v)$ ratio $\mathrm{G}: \mathrm{C}=1: 2, \mathrm{pH}$ Chitosan $\sim 1.8, \mathrm{pH}$ Gellan gum $\sim 12[29]$ \\
\hline Gellan gum & $\mathrm{TiO}_{2}, \mathrm{ZnO}, \mathrm{Ag}$ nanoparticles (NP) & (gram) weight ratio G:NP = 1:0.2, 1:0.4, and 1:0.6 [30] \\
\hline Gum karaya (K) & Chitosan & (gram) Weight ratio K:C = 0.938:0.062 [31] \\
\hline Methacrylated gellan gum (MeGG) & Chitosan & $\begin{aligned} \text { Ratio MeGG:C }= & 2: 1,1: 1, \text { and 1:2. pH MeGG } 5.42(-17 \mathrm{mV}), \mathrm{pH} \\
& \text { Chitosan 4.06 }(+38 \mathrm{mV})[32]\end{aligned}$ \\
\hline Xanthan gum & Chitosan & $\begin{array}{c}\% \text { weight ratio } \mathrm{X}: \mathrm{C}=2: 1,1: 1 \text {, and } 0.5: 1,25^{\circ} \mathrm{C} \text {, volume of each } \\
\text { polymers is } 37.5 \mathrm{~mL}[33]\end{array}$ \\
\hline Xanthan gum & Ozarelix (O) & $\begin{array}{c}\text { Mass ratio } \mathrm{X}: \mathrm{O}=1: 6 \text {, each polymer was dissolved in } \mathrm{pH} 6 \text { of } \\
\text { deionized water [34] }\end{array}$ \\
\hline Carboxymethyl gum kondagogu (CMGK) & Chitosan & $(\% w / v)$ ratio CMGK:C $=0.01: 0.05$ until 0.1:0.2 (statistical studies) [35] \\
\hline Gum ghatti (GG) & Chitosan & $(\% w / v)$ ratio GG:C $=0.1: 0.05$ until 0.5:0.25 (statistical studies) [36] \\
\hline Gum kondagogu (GKG) & Chitosan & Weight ratio GKG:C = 10:1 until 50:1, pH 1.2-6.0 [37] \\
\hline Gum odina (GO) & Chitosan & Weight ratio GO:C = 4:1, 5:1, 6:1. pH 4.5 [38] \\
\hline Xanthan gum & Chitosan & $\begin{array}{l}(\% w / v) \text { ratio } \mathrm{X}: \mathrm{C}=0.7: 0.7 \text { and 1.0:0.7 with } \mathrm{pH} \text { Chitosan } 4.5 \text { and } \\
6.2[39]\end{array}$ \\
\hline Alginate & \multirow{2}{*}{ Chitosan } & \multirow{2}{*}{ Weight ratio polyanion: $\mathrm{C}=75: 75[40]$} \\
\hline Xanthan gum & & \\
\hline Xanthan gum & Cationic guar gum (CGG) & $(\% w / v)$ ratio $\mathrm{X}: \mathrm{CGG}=(0.02-0.18):(0.18-0.02)[41]$ \\
\hline
\end{tabular}


Table 1. Cont.

\begin{tabular}{|c|c|c|}
\hline \multicolumn{2}{|c|}{ Natural Polymers } & Parameters \\
\hline Arabic gum & \multirow[t]{2}{*}{ Chitosan } & $\begin{array}{c}\text { \% weight ratio C: } \mathrm{A}=0.99: 0.01,0.98: 0.02,0.97: 0.03,0.95: 0.05,0.9: 0.1 \\
0.8: 0.2,0.7: 0.3[42]\end{array}$ \\
\hline Pectin/Gum arabic (P/A) & & $\begin{array}{c}\text { \% weight ratio C:P/A * }=0.98: 0.01,0.96: 0.02,0.92: 0.04,0.84: 0.08 \\
0.78: 0.11,0.7: 0.15[42]\end{array}$ \\
\hline Xanthan gum & Chitosan & Ratio $C: X=3: 1,1: 1,1: 3[43]$ \\
\hline Gum Arabic & Gelatin (Gn) & $\%$ weight ratio A:Gn = 2.5:2.5, $\mathrm{pH} 3.5-4.5[44]$ \\
\hline Carboxymethyl gum katira (CGK) & Chitosan & $(\% w / v)$ ratio $\mathrm{CK}: \mathrm{C}=(0.1-0.4):(0.03-0.05)[45]$ \\
\hline Gum Arabic & Cationized gelatin (CGn) & $\begin{array}{c}(\% w / v) \text { concentration of A or CGn }=0.1-1,(v / v) \text { mixing ratio A:CGn } \\
=(1-4):(1-5)[46]\end{array}$ \\
\hline Gum Arabic & $\begin{array}{c}\text { Chitosan } \\
\text { (Low and high molecular weight) }\end{array}$ & Molar ratio C:A = 1:0, 1:0.25; 1:0.5, 1:0.75, 1:1 [47] \\
\hline Sterculia striata rhamnogalacturonoglycan (RG) & Chitosan (high and low molecular weight) & Mixing charge ratio $\left(\mathrm{n}^{+} / \mathrm{n}^{-}\right)=0.1-10[48]$ \\
\hline Gellan gum & Chitosan & $\begin{aligned}(\% w / v) \text { ratio } \mathrm{G}: \mathrm{C}= & 0.85: 0.4, \mathrm{pH} 5 \text { acetate buffer solution, room } \\
& \text { temperature, } 24 \mathrm{~h}[49]\end{aligned}$ \\
\hline Methacrylated gellan gum & Chitosan & $(\% w / v)$ ratio MeGG:C = 1:1, flow rate $50 \mathrm{~mL} /$ hour [51] \\
\hline Borate modified Polyvinyl alcohol (PVA) & Cationic guar gum & $\begin{array}{l}\text { The film PEC is combined with } 0,1,4,7,10 \% \mathrm{wt} \text {. of gold } \\
\text { nanoparticle-nanocellulose filler [52] }\end{array}$ \\
\hline Xanthan gum & \multirow{2}{*}{ Chitosan } & Ratio X:C = 1:1 and 2:1. pH 5.8 and 6.5 [53] \\
\hline Xanthan gum + Polyethylene oxide (PEO) & & Ratio X:PEO:C = 2:0.1:2 and 2:1:2, pH 5.8 and 6.5 [53] \\
\hline Gellan gum & Chitosan & $\% w / v$ ratio $\mathrm{G}: \mathrm{C}=0.04: 0.85, \mathrm{pH} 5.4,80^{\circ} \mathrm{C}, 20 \mathrm{~min}[54]$ \\
\hline Gum Arabic & N,O-carboxymethyl chitosan (NOCC) & $\% w / v$ ratio A:NOCC $=3: 1$ to $7: 1$. Temperature $25^{\circ} \mathrm{C}, \mathrm{pH} 3,8 \mathrm{~h}[55]$ \\
\hline Gum ghatti & \multirow[t]{2}{*}{ Chitosan } & $\begin{array}{r}\text { Mass ratio G:C }=10: 5 \text { and } 15: 5 . \text { With } 100 \mathrm{mg} \text { of lactose or starch, talc } \\
30 \mathrm{mg} \text {, and } 10 \mathrm{mg} \text { of } \mathrm{Mg} \text {-stearate [56] }\end{array}$ \\
\hline Xanthan gum & & $\begin{array}{c}\text { Mass ratio X:C = 10:5 and 15:5. With } 100 \mathrm{mg} \text { of lactose, talc } 30 \mathrm{mg} \text {, and } \\
10 \mathrm{mg} \text { of Mg-stearate [56] }\end{array}$ \\
\hline Carboxymethyl gum katira (CGK) & Chitosan & $(\% w / v)$ ratio CGK:C $=0.5: 0.5[57]$ \\
\hline
\end{tabular}


Table 1. Cont.

\begin{tabular}{|c|c|c|}
\hline \multicolumn{2}{|c|}{ Natural Polymers } & \multirow{2}{*}{$\begin{array}{c}\text { Parameters } \\
\text { Mass ratio G:C }=5: 10,6: 12,7: 14[58]\end{array}$} \\
\hline Gellan gum & Chitosan & \\
\hline Tragacanth gum $(\mathrm{T})$ & Insulin (I) & $\begin{array}{c}(\% w / w) \text { ratio } \mathrm{T}: \mathrm{I}=(0.1,0.5,1): 0.02, \mathrm{pH} \text { of Tragacanth was adjusted to } \\
3.7,4.3,4.6 \text { or } 6[59]\end{array}$ \\
\hline Xanthan gum & Chitosan & $\%$ weight ratio $\mathrm{X}: \mathrm{C}=1.5: 1.5[60]$ \\
\hline Gellan gum & Cationic guar gum & Mixing ratios G:CGG = 10:90 until 90:10, $\mathrm{pH} 3.72,5.5$, and 7.13 [61] \\
\hline Okra gum $(\mathrm{O})$ & Chitosan & Ratio O:C = 10:90 until 90:10, pH 5.0 [62] \\
\hline Gellan gum & Chitosan & $\begin{array}{c}\text { Ratio G:C }=10: 90 \text { until } 65: 35,60^{\circ} \mathrm{C}, \mathrm{pH} \text { Chitosan and Gellan are } 1 \text { and } \\
6 \text {, respectively [64] }\end{array}$ \\
\hline Gum Arabic & Chitosan & Mass ratio $\mathrm{C}: \mathrm{A}=2: 1,3: 1,5: 1,10: 1$ [65] \\
\hline Pectin & Brea gum (B) & Ratio B:P = 1:1, pH Brea gum 2.75 [66] \\
\hline Gellan gum & \multirow{2}{*}{ Gelatin } & \multirow{2}{*}{ Polysaccharide added $1.5 \%$ of the dry content modified gelatin [67] } \\
\hline Xanthan gum & & \\
\hline Gum Arabic & Fish gelatin & $\%(\mathrm{~g}$ of $\mathrm{A} / 100 \mathrm{~g}$ of $\mathrm{Gn})=0,15,25,35.150 \mathrm{rpm}, 15 \mathrm{~min}, 25^{\circ} \mathrm{C}[69]$ \\
\hline Sterculia striata gum (CHG) & Chitosan & $(w / w)$ ratio $C: \mathrm{CHG}=4: 1, \mathrm{n}^{+} / \mathrm{n}^{-}=10[70]$ \\
\hline Gellan gum & Chitosan & $\begin{array}{c}(\% w / w) \text { ratio } \mathrm{C}: \mathrm{G}=80: 20 \text { and } 60: 40.60^{\circ} \mathrm{C} \text {, Gellan gum solution was } \\
\text { dropped into the Chitosan solution, } \mathrm{pH} 6[71]\end{array}$ \\
\hline Xanthan gum & Chitosan & $\begin{array}{l}(\% w / v) \text { ratio } \mathrm{C}: \mathrm{X}=0.65: 0.65 . \mathrm{pH} \text { Chitosan } 3.6,4.6 \text {, and } 5.6(\text { by } \mathrm{HCl} \\
\left.\text { and } \mathrm{CH}_{3} \mathrm{COOH}\right) \text {, mixing ratio } \mathrm{C}: \mathrm{X}=1: 1[72]\end{array}$ \\
\hline Xanthan gum & Chitosan/Hydroxyapatite nanoparticle (NHA) & Weight ratio X:C:NHA = 30:30:40, 25:25:50, and 20:20:60 [73] \\
\hline Arabinogalactans gum acacia (GA) & \multirow{4}{*}{ Zein } & \multirow{4}{*}{$\begin{array}{c}\text { Final volume ratio polysaccharide:Zein = 1:1 (concentration of each } \\
\text { polymers is } 1 \mathrm{mg} / \mathrm{mL} \text { ), two methods were used: nanoprecipitation (n) } \\
\text { and desolvation (d) [74] }\end{array}$} \\
\hline Acacia mearnsii gum (GN) & & \\
\hline Glucuromannans gum ghatti (GGG) & & \\
\hline Vochysia thyrsoidea gum (VT) & & \\
\hline
\end{tabular}

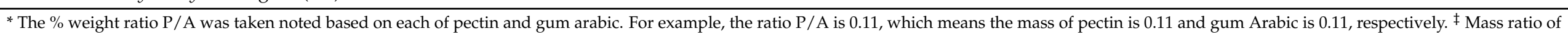
chitosan is the sum of the mass combination of gallic acid and chitosan. 


\subsection{The Ratio of Polyanion and Polycation}

\subsubsection{Particle Size}

The charge ratio of chitosan and gum show interesting results on the particle size distribution of PEC. $\mathrm{n}^{+} / \mathrm{n}^{-}$between chitosan and carboxymethylated gum cashew (CMGC) has relation with the concentration of CMGC, increasing the gum concentration overall charge ratio produces larger particle size for the degree of substitution CMCG 0.16 and 0.36 [27]. The effect of charge ratio is more significant on the molecular weight of chitosan, higher $\mathrm{n}^{+} / \mathrm{n}^{-}$have larger particle size for the combination of low $\left(7.8 \times 10^{4} \mathrm{~g} \mathrm{~mol}^{-1}\right)$ and high molecular weight chitosan $\left(4.6 \times 10^{5} \mathrm{~g} \mathrm{~mol}^{-1}\right)$ with Sterculia striata rhamnogalacturonoglycan. However, low molecular weight chitosan produces a bigger particle size than the high molecular weight [48]. The effect of the weight ratio of carboxymethyl gum kondagogu (CMGK) to chitosan was more significant than that of chitosan to CMGK. A higher ratio of CMGK to chitosan produced a bigger particle size than the higher ratio of chitosan to CMGK [35]. A similar trend was also observed for PEC made of gum ghatti/Pluronic F$127 /$ chitosan. The combination of Pluronic was quite prominent for the growth of particles, but it can be attenuated at a higher concentration of gum ghatti in the system [36]. The size of polyelectrolyte nanoparticles synthesized from carboxymethyl gum katira (CK)-chitosan was more influenced by the concentration of CK than chitosan [45]. The increased gellan gum concentration to chitosan with the same weight ratio of 1:2 produced a larger particle size for the entrapment of Tamoxifen citrate [58].

In contrast, gum Arabic has opposite results on the particle size with the increasing concentration. Tsai and co-authors analyzed the combination of chitosan, pectin, and gum Arabic PEC; the result is that increasing the concentration of gum Arabic in chitosan solution reduces the particle size significantly. Meanwhile, the combination of pectin + gum Arabic combined in chitosan solution showed an uneven particle size distribution with the rising polysaccharide concentration [42]. Sarika and co-workers who investigated the cationized gelatin/gum Arabic PEC also stated that a higher volume ratio of gum Arabic produced a clear PEC and smaller particle size ranging from 60 to $170 \mathrm{~nm}$ [46]. Hu et al. (2016) studied the formation of PEC from gallic acid-chitosan conjugate and gum Arabic; a higher ratio of gum Arabic produced smaller particle size, which is similar to the results of Tsai and co-authors [50]. With these results, the effect on particle size depends on the type of gums. Gum Arabic has the opposite behavior to the other gums since it has different chemical compositions. Several researchers mentioned that the more viscous gum produces a larger particle size; this also correlates with the chain flexibility of the gum itself $[36,45,48]$.

For drug delivery applications, some studies have shown that the particle size of drug-loaded particles is more affected by the polymer ratio than the drug concentration. Narkar et al. investigated the effect of chitosan-coated amoxicillin gellan beads, raising the gellan gum concentration with the same antibiotic and chitosan concentration gave a slightly bigger diameter of particle size, $0.86 \pm 0.6 \mathrm{~mm}$ and $0.91 \pm 0.7 \mathrm{~mm}$ for $1.5 \%$ and $1.75 \% w / v$ gellan solution, respectively [24]. In the preparation of PEC chitosome, the drying method has a significant impact on the particle size. Higher ratio $(\% w / w)$ of xanthan gum to chitosan resulted in larger particle size of chitosome for ratio 1:1 and 2:1; this is valid for $60 \mathrm{mg} / \mathrm{mL}$ [33]. The results are interesting since the size of the $60 \mathrm{mg} / \mathrm{mL}$ liposome size is smaller $(195 \pm 59 \mathrm{~nm})$ than the $30 \mathrm{mg} / \mathrm{mL}(247 \pm 97 \mathrm{~nm})$. Another study performed by Manconi et al. [26] showed that the weight ratio of xanthan gum and chitosan 2:0.5 has a bigger size of chitosomes than the ratio of 8:0.5; however, this is influenced by the different drying methods of chitosomes [26]. The chitosomes produced at a ratio of xanthan gum and chitosan of 2:0.5 were dried using freeze-dry, while the ratio of 8:0.5 was spray dried.

\subsubsection{Mechanical Properties}

Besides particle size, the ratio of biopolymer in PEC also plays a crucial role in the mechanical properties of PEC. Several studies show that gum in the natural cationic 
polymer affects the rheological structure, such as storage modulus $\left(G^{\prime}\right)$, loss modulus $\left(G^{\prime \prime}\right)$, and tensile strength. Chitosan membrane has better tensile stress and elongation capability than gum Arabic or pectin membrane that were too fragile to be measured. The addition of gum Arabic in the chitosan membrane improved the tensile strength of than pectinchitosan membrane. However, gum Arabic did not improve the elongation properties of the chitosan membrane [25]. The study by Tsai et al. (2014) using the combination of pectin/gum Arabic/chitosan gave similar results; the best tensile strength was obtained at the ratio of $\mathrm{C}: \mathrm{P} / \mathrm{A}$ at 0.84:0.8. However, the higher pectin/gum Arabic ratio did not change the tensile strength [42]. The high molecular weight of chitosan (HMWC) has better puncture strength than the lower one (LMWC). A small ratio of gum Arabic in high molecular weight chitosan film $(0.25: 1$ and $0.5: 1)$ significantly decreased the puncture strength of pure chitosan film. Higher ratio gum Arabic-HMWC (0.75:1 and 1:1) showed better mechanical properties than the native HMWC film. The addition of gum Arabic does not improve the elongation of gum Arabic-chitosan film [47].

Spray-dried chitosomes with a low ratio of xanthan gum to chitosan $(2: 0.5 \% w / w)$ have a predominance of viscous over elastic properties. Freeze-dried chitosome has higher $\mathrm{G}^{\prime}$ than $\mathrm{G}^{\prime \prime}$ with all ratio xanthan and chitosan, however increasing xanthan concentration cause decreasing value of $G^{\prime}$ and $G^{\prime \prime}$. With the increasing concentration $(2-10 \% w / w)$, pure xanthan gum solution showed higher $\mathrm{G}^{\prime}$ than $\mathrm{G}^{\prime \prime}$; this behavior shows the reinforcement of chitosan and xanthan in the PEC network formation depend on the drying methods [26]. A similar trend of spray-dried xanthan gum/chitosan with a mixture of liposomes was also exhibited by Manca et al. (2012); $G^{\prime}$ was always higher than $G^{\prime \prime}$ at all ratios of chitosan to xanthan gum [33].

The prevalence of elastic over viscous material is advantageous for developing a mucoadhesive system since more elastic properties indicate stronger interaction between the PEC and the biological matrix [26,33]. Kim and co-authors investigate the gel formulation of chitosan-xanthan gum with concentration $6 \%$ and $9 \%$ gel, the shear stress for $6 \%$ gel for all ratio chitosan and xanthan developed in orderly profile, which at low shear rate means low shear stress [53]. However, the $9 \%$ gel showed a disorder shear stress profile at certain chitosan and xanthan gum PEC parameters. The rheological property is greatly affected by the composition ratio of biopolymer; the whole parameters of gel indicate shear-thinning behavior. Magnetic xanthan gum and chitosan hydrogel (MPECH) showed better $\mathrm{G}^{\prime}$ and $G^{\prime \prime}$ than the original PEC hydrogel (PECH), the value of $G^{\prime}$ is always higher than $G^{\prime \prime}[60]$. The addition of magnetic nanoparticles to $\mathrm{PECH}$ improves the compressive strength of the original PECH at a strain rate of 90\%, MPECH and PECH have a stress value of 0.042 and 0.037 , respectively.

The different types of acids used for $\mathrm{pH}$ adjustment also influence the rheological behavior; Ćirić et al. (2020) show that the chitosan/xanthan gum PEC that adjusted with acetic acid has +a higher hysteresis area than hydrochloric acid [72]. This phenomenon indicates that chitosan possesses the best interactions with xanthan gum in the acetic acid solution at $\mathrm{pH}$ 3.6. Combining xanthan gum/chitosan and hydroxyapatite nanoparticles has the best compressive strength and modulus at ratio 25:25:50 for X:C:NHA, decreasing polysaccharide content in the PEC while increasing NHA would make insufficient binding excess NHA [73].

Increasing the ratio of gum Arabic to NOCC at 7:1 reduced the $\mathrm{G}^{\prime}$ and $\mathrm{G}^{\prime \prime}$ values, and the viscoelastic properties depended on the frequency, which can be said to follow the viscoelastic nature of gum Arabic solution [55]. Meanwhile, increasing gum concentration in the Chitosan-Gum Odina complex resulted in a higher loss in modulus than storage modulus [38], the highest mechanical strength for the ratio of gum Odina and Chitosan was $5: 1$, which produced the highest $G^{\prime \prime}$ and $G^{\prime}$ at low strain percentage $(0.1-2 \%)$. The addition of acid-resistant materials (cellulose acetate phthalate) in the gelatin film caused a significant drop in the viscosity and shear stress, which risk the ability of gelatin to form the film. A small amount of gellan gum and xanthan gum could increase the viscosity and shear stress of gelatin-acid resistant mixture [67]. No significant change of $G^{\prime}$ and $G^{\prime \prime}$ 
was observed for the increasing mixing ratio of mesquite gum and chitosan insoluble PEC, the loss modulus was always higher than the storage modulus [68] which is similar to the study of gum Arabic and NOCC insoluble PECs. Higher ratio of gellan gum (40:60) in the chitosan-gellan gum hydrogel show three times higher elastic modulus than the ratio of gellan gum to chitosan 80:20 [71].

\section{2. $p H$}

The mechanism of PEC formation is based on the electrostatic interaction of two oppositely charged polymers. Hence, it is necessary to understand the charge characteristic of material at a specific $\mathrm{pH}$ range. Potentiometric titration can be conducted to know the effect of pH on the polymer state. Da Silva et al. (2015) show that gum Arabic has two $\mathrm{pH}$-dependent species: uronic acid and amino acid (gum residue). Gelatin has an amino acid group that is also $\mathrm{pH}$-dependent; both polymers indicated that the $\mathrm{pH}$ of $2-4$ has a more pronounced contribution to the overall titration curve. The uronic acid of commercial gum Arabic, which has a pKa value of around 3.61, has the optimum interaction with gelatin at $\mathrm{pH} 4$ [44]. Chitosan and gum Odina PEC have an equivalent stoichiometric charge ratio of both polysaccharides with the ratio of $\mathrm{O}: \mathrm{C}$ at 5:1 [38]. Circumstantially, the ratio of the polymer affects the potentiometric titration. This phenomenon can be correlated to the higher mass in the solution, which means more ionic linkage is needed to neutralize the functional group ion. Lankalapalli and Kolapalli (2012) also investigated the association between mixing ratio and $\mathrm{pH}$ in the formation PECs of gum karaya and chitosan; less ratio of gum karaya in the chitosan solutions means lower $\mathrm{pH}$ and higher conductivity [31].

\subsubsection{Zeta Potential}

Comprehending single natural polymer $\mathrm{pH}$ characteristics needs to be considered one of the most critical roles in the complex formation of polyelectrolyte. The zeta potential versus $\mathrm{pH}$ analysis must be carried out to locate the isoelectric point ( $\mathrm{pI}$ ) with no potential charge at a specific $\mathrm{pH}$ value. Sarika and co-authors (2015) investigated the effect of $\mathrm{pH}$ on cationized gelatin/gum Arabic complex with mixing ratio 1:1 $(v / v)$ with each polymer concentration $0.1 \% w / v$; it can be seen at low $\mathrm{pH}(<4)$ the cationized gelatin $(\mathrm{CGn})$ and gum Arabic (A) have a positive and negative charge, respectively. The appearance of the CGn/A complex depended on $\mathrm{pH}$; the zeta potential of PEC changed significantly, unlike the natural polymer mixtures. The turbidity of PEC showed a drastic increase up to $\mathrm{pH}$ 6.6, which is attributed to the strong electrostatic interactions between amino groups on CGn and carboxylate groups on A [46]. The zeta potential of HMWC is higher than LMWC at $\mathrm{pH}$ 4, and the combination of A and HMWC at different molar ratios showed higher potential than LMWC/A at $\mathrm{pH} 4-5.5$. The turbidity of chitosan and gum Arabic was more prominent at $\mathrm{pH} 5.5$ than $\mathrm{pH} 4$ and 5 due to high solubility and high degree ionization of gum at higher $\mathrm{pH}(\sim 7)$ [47]. This result is similar to the study of chitosan and gum Arabic PEC by Hu and co-authors (2016); higher $\mathrm{pH}$ produced more turbid PEC and smaller zeta potential. The optimum $\mathrm{pH}$ of interaction gum Arabic and chitosan to form PEC was five since it yields the highest count rate, small particle size, and most homogeneous distribution [50]. The molar charge ratio of HMWC or LMWC with Sterculia striata rhamnogalacturonoglycan (RG) on zeta potential is more favorable toward the high charge ratio of LMWC and RG than the mixture of HMWC/RG. This result indicates that HMWC has better interaction with the polyanion RG than LMWC, confirmed by the more significant charge compensation due to higher consumption of amino groups on HMWC [48].

Knowing the zeta potential of the material is advantageous to understand the mechanism of PEC further. Zeta potential is more dependent on $\mathrm{pH}$ than the mixing ratio of natural polymer. For the case of cationic guar gum (CGG) and gellan gum (G), different $\mathrm{pH}$ with the same mixing ratio (CGG: $\mathrm{G}=70: 30$ ) yield significantly different zeta potential. Kaur and Kaur (2018) mentioned that pH 5.5 show the lowest zeta potential value, which indicates the maximum favorable interaction between CGG and G; the species distribution 
profile of CGG also supports this with $>90 \%$ in protonated hydroxyl group $\mathrm{H} 3 \mathrm{O}+$ and $\mathrm{G}$ with $>90 \%$ in deprotonated carboxylate ions COO-. The highest turbidity and lowest transmittance were demonstrated at $\mathrm{pH} 5.5$ indicated nonstoichiometric insoluble complexes of CGG and G [61]. This result is also very similar to the study by Nur and co-author (2018), who chose $\mathrm{pH} 4.6$ and ratio 0.02:0.5 (I:T) as the best condition for insulin (I) and tragacanth gum (T) PEC, which also exhibited the highest zeta potential value $(-7.5 \mathrm{mV})$ compared to other $\mathrm{pH}$ and ratio [59]. The selection of $\mathrm{pH}$ is based on the $\mathrm{pI}$ insulin around 5.5-6.4; below the pI value, insulin is positively charged. This result coincides with the potential value of tragacanth gum to be negatively charged at $\mathrm{pH}$ 4.6. Unlike the study of brea gum and pectin, both do not have an opposite charge at the same $\mathrm{pH}$. Brea gum has a positive charge below $\mathrm{pH} 3.7$, while pectin negatively charges its natural solution. Therefore, to prepare hydrogel PEC from both materials, the authors mix each solution at a separated $\mathrm{pH}$ of 2.75 and unadjusted $\mathrm{pH}$ conditions for brea gum and pectin, respectively [66]. The strength of the electrostatic interaction (SEI) also can be calculated to know the optimum $\mathrm{pH}$ of the interaction among the two opposite charged polymers. For instance, Rodríguez et al. determined the SEI value between mesquite gum and chitosan which is also correlated with the zeta potential for each natural polymer [68].

\subsubsection{Swelling Behavior}

$\mathrm{pH}$ is an essential parameter in the swelling studies of PEC. This parameter correlates to the mechanical properties of the material with the effect of ions in the solution. The investigation of swelling studies is necessary to understand whether the PEC is suitable for oral route drug delivery. The Human GI tract is differentiated into three different $\mathrm{pH}$, the stomach has a $\mathrm{pH}$ range around 1.2-2.2, the duodenum has a value of 5.8, and the jejunum has a $\mathrm{pH}$ of 6.8. Argin and co-authors prepared xanthan-chitosan hydrogels to deliver probiotics to the intestines [39]. The xanthan-chitosan PEC hydrogels were tested in simulated gastric fluid (SGF) and simulated intestinal fluid (SIF) with $\mathrm{pH} 2$ and $\mathrm{pH}$ 6.2, respectively. It was observed that xanthan $(\mathrm{X})$-chitosan $(\mathrm{C})$ hydrogel is $\mathrm{pH}$-responsive; it did not swell in SGF and rapidly swell for the first $2 \mathrm{~h}$ in SIF. Higher xanthan ratio (1\%) swell faster than the low content of xanthan $(0.7 \%)$, the best swelling resulted in ratio X:C of $1: 1$.

Other studies by Li et al. indicated the same 1:1 ratio of chitosan-xanthan gum film matrix showed constant swelling at $\mathrm{pH} 1.2$ (SGF) for $2 \mathrm{~h}$ and slightly swollen at $\mathrm{pH} 6.8$ (SIF) for the next $22 \mathrm{~h}$. While the film erosion indicated a slightly reduced of the remaining mass in SGF, and subsequently in SIF, this indicated the stable complex formation of PEC in the simultaneous immersion on SGF and SIF [40]. Shao and co-authors (2015) have a similar swelling profile behavior of drug-loaded X-C matrix tablet; however, the erosion behavior is different with $\mathrm{Li}$ et al. since they also take account of the amount of drug release at time $t$ [43]. These authors used high molecular weight chitosan: $370 \mathrm{kDa}$ and $400 \mathrm{kDa}$ with degree acetylation of $85-86.5 \%$.

For chitosome made of chitosan and xanthan with two different drying methods (freeze-dried and spray dried), freeze-dried chitosome has a higher swelling ratio than spray dried. However, the freeze-dried chitosome has the highest swelling ratio after more than $5 \mathrm{~h}$ of immersion in SGF compared to the SIF medium, while the spray-dried chitosome did not show any appreciable differences [26]. Chitosan-coated amoxicillin gellan beads have a higher swelling ratio at $\mathrm{pH} 7.4$ than $\mathrm{pH} 1.2$ due to deprotonation amino groups of chitosan and the predominate swelling effect of gellan in alkaline conditions [24].

Chitosome has a different swelling profile than the other previously mentioned xanthan gum-chitosan PEC can be caused by a higher ratio of xanthan in the chitosome $(\mathrm{X}: \mathrm{C}=2: 0.5)$ and the inclusion of liposomes in the preparation. Gum kondagogu (GKG) and chitosan hydrogel have $\mathrm{pH}$-dependent swelling; low $\mathrm{pH} 1.2$ showed high swelling index compared to more alkaline $\mathrm{pH}$ conditions ( $\mathrm{pH} 5,6.8,8)$. This result is similar to the previous chitosome; the GKG-C hydrogel is synthesized with a high gum ratio. Kim et al. investigated the swelling effect on two different $\mathrm{pH}$ of preparation X-C PEC $(\mathrm{pH} 5.8$ and 
6.5); it was observed that $\mathrm{pH} 6.5 \mathrm{X}-\mathrm{C}$ PEC has a higher swelling ratio than $\mathrm{pH} 5.8 \mathrm{PEC}$. The swelling study was conducted in distilled water for $4 \mathrm{~h}$, which showed a prominent effect of $\mathrm{pH}$ in the preparation method on the swelling behavior.

\subsection{Mixing Order}

The mixing sequence between the cationic and anionic natural polymers affected the PEC properties (particle size, tensile strength, and stability). Few studies were conducted to understand further the effect of mixing order in the PEC, but clearly, it significantly influenced the resulting PEC. Silva et al. (2010) explored mixing order as a function of CMCG degree substitution (DS); when chitosan was added to CMCG 0.36 , the composite has a larger particle size than CMCG 0.36 was added to chitosan [27]. This result is similar to CMCG 0.16, but it produced a smaller particle size than the CMCG 0.36. Amin and co-authors did an interesting study of mixing order between chitosan (C) and gellan gum (GG). They investigated the sequence of PEC film preparation on the mechanical properties. The addition of GG to $C$ improved Young's modulus and tensile strength by 1.7 and 2.7 times, respectively. While $C$ was added to $G G$, it produced particles with better toughness (3.6 fold) than GG into C. Both mixing orders show little difference in their water vapor transmission rates [29].

The influence of the molecular weight of chitosan and the charge ratio was studied towards the mixing order between chitosan and RG. High MW C/RG produced a larger particle size than high $\mathrm{RG} / \mathrm{C}$ at a charge ratio of 0.8 . Fluctuate particle size profile was observed at a high charge ratio of 4 to 10 . On the contrary, low MW C/RG or RG/low MW $\mathrm{C}$ has a similar particle size in low charge ratio $(0.2-0.8)$; it has a larger particle size for low MW C/RG in charge ratio of 6-10 than RG/low MW C. The stability of PEC particle size was good (up to 30 days) for low MW C despite the mixing order at a charge ratio of 0.1 and 5 [48].

A recent study by da Silva and co-authors (2020) has proven that mixing order was influential in the resulting PEC. The authors studied the PEC preparation from zein and several polysaccharides. There are two terms used by da Silva et al. to investigate the mixing order of PEC. If zein were added to the polysaccharide, it would be described as nanoprecipitation. For the opposite case (polysaccharide to zein), it will be called desolvation. Based on their results, we can understand that the mixing order significantly affects particle size. On the zein control sample of desolvation and nanoprecipitation, the particle size of the desolvation method is 3.4 times smaller than the nanoprecipitation method. However, the most intriguing result of mixing order against all polysaccharides is smaller for nanoprecipitation of zein to polysaccharide solution. This result explains that zein diffusion was relatively easier due to its lower molar mass; the polysaccharide could accommodate zein to stabilize the formed particle [74].

\section{Gum-Based PECs for Biomedical Applications}

Natural gums are composed of heterogenous monosaccharides, including glucose, galactose, rhamnose, arabinose, xylose, mannose, uronic acids that construct threedimensional interconnected molecular networks. The structure majorly modulates the intensity of the gels' coordination and gum composition in accompanies with the ionic strength, $\mathrm{pH}$, and temperature [75]. As a biopolymer, natural gums present outstanding biocompatibility/cytocompatibility, biodegradability, and water solubility. The rule out the possibility of human body rejection makes the natural gums a priority in tissue engineering applications. Moreover, most gums are secure to be consumed, which can easily proceed towards the drug delivery field [76]. Compared to synthetic polymers, the availability, lower toxicity, and best-economic aspect become the critical value of natural gums [77].

Nevertheless, these advantages are accompanied by several drawbacks: thickening effect, high swelling, $\mathrm{pH}$-dependent solubility, susceptibility of microbial contamination, and the complexity of viscosity adjustment due to relatively rapid biodegradation [75]. Therefore, chemical modification is required for improving their features in biomedical 
applications. Based on the natural gums chemical structure, the existence of acetic, pyruvic, carboxyl groups residual side chains make several types of NG as negatively charge biopolymers that create the possibility of incorporating oppositely charged biopolymers such as chitosan and cationic modified non-ionic gum and synthetic polymer (e.g., acrylic ion exchange resin and polyvinyl alcohol, Polyethylene oxide)). As the most common natural polycationic, chitosan presents positively charged amino groups that form polyelectrolytes complexes towards anionic groups of NG through electrostatic interaction, dipole-dipole interaction, and hydrogen bonding [78]. A summary of Gum-based PECs with various polycationic modified and their biomedical application are briefly summarized in Table 2 .

Table 2. Gum-based PECs for biomedical application for: (A) Tissue and bone regeneration; and (B) Cargo delivery.

\begin{tabular}{|c|c|c|c|c|}
\hline \multicolumn{5}{|c|}{ A Tissue and Bone Regeneration } \\
\hline \multicolumn{2}{|c|}{ Gum-Based PECs Composite } & \multicolumn{2}{|c|}{ Carrier Form } & Application \\
\hline $\begin{array}{r}\text { Methacryla } \\
\text { Gum-Chitosan/Arginy }\end{array}$ & $\begin{array}{l}\text { Gellan } \\
\text { lycylaspartic acid }\end{array}$ & \multicolumn{2}{|c|}{ Hydrogel Fibers } & Tissue engineering [51] \\
\hline Xanthan Gum-Chitosa & Magnetic $\mathrm{Fe}_{3} \mathrm{O}_{4}$ & \multicolumn{2}{|c|}{ Hydrogel Scaffolds } & Tissue engineering [60] \\
\hline Gellan Gum & hitosan & \multicolumn{2}{|c|}{ Hydrogel Scaffolds } & Tissue engineering [64] \\
\hline Xanthan Gum-Chitosa & /Hydroxyapatite & \multicolumn{2}{|c|}{ Scaffolds } & Bone-Regeneration [73] \\
\hline \multicolumn{5}{|c|}{ B Cargo Delivery } \\
\hline $\begin{array}{l}\text { Gum-Based PECs } \\
\text { Composite }\end{array}$ & Cargo Model & Carrier Form & Application & Release Parameter \\
\hline $\begin{array}{l}\text { Xanthan Gum-Chitosan } \\
\text { (Spray Dried) coated } \\
\text { Liposomes }\end{array}$ & \multirow[t]{2}{*}{ C-phycocyanin } & \multirow[t]{2}{*}{ Tablets } & \multirow{2}{*}{$\begin{array}{l}\text { Colon-Specific } \\
\text { delivery [26] }\end{array}$} & $\begin{array}{c}\mathrm{t}_{\sim 18 \%}=24 \mathrm{~h}(\text { Simulated Gastric } \\
\text { Fluid }\left(\mathrm{SGF} ; \mathrm{pH} 2 ; \mathrm{T}=37^{\circ} \mathrm{C}\right) \\
\mathrm{t} \sim 39 \%=24 \mathrm{~h}(\text { Simulated } \\
\text { Intestinal Fluid (SIF); pH 6,8; } \\
\left.\mathrm{T}=37^{\circ} \mathrm{C}\right)\end{array}$ \\
\hline $\begin{array}{c}\text { Xanthan Gum-Chitosan } \\
\text { (Freeze Dried) coated } \\
\text { Liposomes }\end{array}$ & & & & $\begin{array}{c}\mathrm{t}_{\sim 48 \%}=24 \mathrm{~h}(\text { Simulated Gastric } \\
\text { Fluid }\left(\mathrm{SGF} ; \mathrm{pH} 2 ; \mathrm{T}=37^{\circ} \mathrm{C}\right) \\
\mathrm{t}_{\sim 68}=24 \mathrm{~h}(\text { Simulated } \\
\text { Intestinal Fluid (SIF); } \mathrm{pH} 6,8 ; \\
\left.\mathrm{T}=37^{\circ} \mathrm{C}\right)\end{array}$ \\
\hline Gellan Gum-Chitosan & $\begin{array}{l}\text { Amoxicillin } \\
\text { trihydrate }\end{array}$ & Hydrogel Beads & $\begin{array}{l}\text { Gastrointestinal } \\
\text { Delivery [24] }\end{array}$ & $\begin{array}{c}\mathrm{t}_{\sim 83 \%}=24 \mathrm{~h}(0.1 \mathrm{M} \mathrm{HCl} ; \mathrm{pH} \\
\left.1,2 ; \mathrm{T}=37^{\circ} \mathrm{C}\right)\end{array}$ \\
\hline $\begin{array}{l}\text { Gum Karaya } \\
\text { (GK)-Chitosan }\end{array}$ & $\begin{array}{l}\text { Diclofenac Sodium } \\
\text { (DS) }\end{array}$ & Tablets & Oral Delivery [31] & $\begin{array}{l}t_{92,94 \%}=24 \mathrm{~h}(\text { Phosphate } \\
\left.\text { Buffer; pH 7.4; } \mathrm{T}=37^{\circ} \mathrm{C}\right)\end{array}$ \\
\hline $\begin{array}{l}\text { carboxymethyl gum } \\
\text { kondagogu-chitosan }\end{array}$ & Ofloxacin (OX) & Nanoparticles & - & $\begin{array}{c}\mathrm{t}_{50 \%}=24 \mathrm{~h}(\text { Phosphate Buffer; } \\
\left.\text { pH 7.4; } \mathrm{T}=37^{\circ} \mathrm{C}\right)[35]\end{array}$ \\
\hline $\begin{array}{l}\text { Gum Ghatti-Chitosan@ } \\
\text { Pluronic F-127 }\end{array}$ & Ofloxacin & Nanoparticles & $\begin{array}{c}\text { Drug Delivery and } \\
\text { Antibiotic activity [36] }\end{array}$ & $\begin{array}{c}t_{32} \%=12 \mathrm{~h} \\
\text { (Phosphate Buffer; } \mathrm{pH} \\
7.4 ; \mathrm{T}=37^{\circ} \mathrm{C} \text { ) }\end{array}$ \\
\hline Gum Odina-Chitosan & - & Microspheres & $\begin{array}{c}\text { Colon-specific } \\
\text { delivery [38] }\end{array}$ & - \\
\hline Xanthan gum-Chitosan & $\begin{array}{l}\text { Pediococcus } \\
\text { acidilactici cells }\end{array}$ & $\begin{array}{l}\text { Hydrogel } \\
\text { microspheres }\end{array}$ & $\begin{array}{l}\text { Gastrointestinal } \\
\text { Delivery [39] }\end{array}$ & $\begin{array}{c}\mathrm{t}_{\text {negligible }}=2 \mathrm{~h} \text { (Simulated } \\
\text { Gastric Fluid (SGF; pH } 2 ; \\
\left.\mathrm{T}=37^{\circ} \mathrm{C}\right) \\
\mathrm{t}_{100 \%}=5 \mathrm{~h}(\text { Simulated } \\
\text { Intestinal Fluid (SIF); pH 6,8; } \\
\left.\mathrm{T}=37^{\circ} \mathrm{C}\right)\end{array}$ \\
\hline $\begin{array}{l}\text { Cationic guar } \\
\text { gum-Xanthan Gum }\end{array}$ & Diclofenac Sodium & Microspheres & $\begin{array}{l}\text { Gastrointestinal } \\
\text { Delivery [41] }\end{array}$ & $\begin{array}{c}\mathrm{t}_{61.02 \%}=12 \mathrm{~h} \\
\text { (Phosphate Buffer; } \mathrm{pH} \\
7.4 ; \mathrm{T}=37^{\circ} \mathrm{C} \text { ) }\end{array}$ \\
\hline
\end{tabular}


Table 2. Cont.

\section{B Cargo delivery}

\section{Gum-Based PECs Composite}

Xanthan gum-Chitosan

Theophylline (Th)

Metoprolol

succinate (MS)

Tablets

Alginate-Chitosan Theophylline (Th)

Metoprolol

succinate (MS)

\section{Carrier Form}

Oral Delivery [40]

Application

$\mathrm{t}_{\sim 28 \%}=2 \mathrm{~h} ; \mathrm{t}_{\sim 99.8 \%}=24 \mathrm{~h}$;

(Simulated Gastric Fluid (SGF)

for $2 \mathrm{~h}$ followed with

Simulated Intestinal fluid (SIF)

for $22 \mathrm{~h}$; $\mathrm{pH} \mathrm{1,2} \mathrm{and} 7.4$ respectively; $\mathrm{T}=37^{\circ} \mathrm{C}$ )

$\mathrm{t}_{\sim 37 \%}=2 \mathrm{~h} ; \mathrm{t}_{\sim 92 \%}=24 \mathrm{~h}$

(Simulated Gastric Fluid (SGF) for $2 \mathrm{~h}$ followed with

Simulated Intestinal fluid (SIF) for $22 \mathrm{~h}$; $\mathrm{pH} 1,2$ and 7.4 respectively; $\mathrm{T}=37^{\circ} \mathrm{C}$ ) $\mathrm{t}_{\sim 18 \%}=2 \mathrm{~h} ; \mathrm{t}_{\sim 84 \%}=24 \mathrm{~h} ;$

(Simulated Gastric Fluid (SGF) for $2 \mathrm{~h}$ followed with

Simulated Intestinal fluid (SIF) for $22 \mathrm{~h} ; \mathrm{pH} 1,2$ and 7.4 respectively; $\mathrm{T}=37^{\circ} \mathrm{C}$ ) $\mathrm{t}_{\sim 37 \%}=2 \mathrm{~h} ; \mathrm{t}_{\sim 96 \%}=24 \mathrm{~h}$;

(Simulated Gastric Fluid (SGF) for $2 \mathrm{~h}$ followed with

Simulated Intestinal fluid (SIF) for $22 \mathrm{~h}$; $\mathrm{pH} \mathrm{1,2} \mathrm{and} 7.4$ respectively; $\mathrm{T}=37^{\circ} \mathrm{C}$ )

\begin{tabular}{|c|c|c|c|c|}
\hline $\begin{array}{l}\text { carboxymethyl gum } \\
\text { katira-Chitosan }\end{array}$ & Ofloxacin & Nanoparticles & Ophthalmic delivery [45] & $\begin{array}{c}\mathrm{t}_{\sim 92 \%}=24 \mathrm{~h}(0.1 \mathrm{M} \mathrm{HCl} ; \mathrm{pH} \\
\left.1,2 ; \mathrm{T}=37^{\circ} \mathrm{C}\right)\end{array}$ \\
\hline Xanthan gum-Chitosan & $\begin{array}{c}\text { Combination of } \\
\text { Valproic acid (VPA) } \\
\text { and sodium } \\
\text { valproate (VPS) } \\
\text { with ratio } 1: 2\end{array}$ & Tablets & Oral Delivery [43] & $\begin{array}{c}\mathrm{t}_{4.8 \%}=1 \mathrm{~h} ; \mathrm{t}_{95 \%}=24 \mathrm{~h} \\
\text { (Simulated Gastric Fluid (SGF) } \\
\text { for } 1 \mathrm{~h} \text { followed with } \\
\text { Phosphate Buffer for } 23 \mathrm{~h} ; \mathrm{pH} \\
1,2 \text { and } 6.8 \text { respectively; } \\
\mathrm{T}=37^{\circ} \mathrm{C} \text { ) }\end{array}$ \\
\hline $\begin{array}{l}\text { Rhamnogalacturonoglycan } \\
\text { (Rh)-Chitosan (low } \\
\text { molecular weight) } \\
\text { (Mixing charge ratio } \\
\left.\mathrm{n}^{+} / \mathrm{n}^{-} 5\right)\end{array}$ & \multirow{2}{*}{ Chloroquine } & \multirow{2}{*}{ Nanoparticles } & \multirow{2}{*}{$\begin{array}{l}\text { Localized Drug Delivery } \\
\text { (Malaria } \\
\text { Chemotherapy) [48] }\end{array}$} & $\begin{array}{c}\mathrm{t}_{\sim 60 \%}=10 \mathrm{~h} ; \mathrm{t}_{100 \%}=12 \text { days } \\
\text { (Phosphate Buffer; } \mathrm{pH} 7.4 \\
\left.\mathrm{~T}=25^{\circ} \mathrm{C}\right)\end{array}$ \\
\hline $\begin{array}{l}\text { Rhamnogalacturonoglycan } \\
\text { (Rh)-Chitosan (low } \\
\text { molecular weight) } \\
\text { (mixing charge ratio } \\
\mathrm{n}^{+} / \mathrm{n}^{-} 0.1 \text { ) }\end{array}$ & & & & $\begin{array}{c}\mathrm{t}_{\sim 40 \%}=24 \mathrm{~h} ; \mathrm{t}_{100 \%}=12 \text { days } \\
\text { (Phosphate Buffer; } \mathrm{pH} 7.4 \\
\left.\mathrm{~T}=25^{\circ} \mathrm{C}\right)\end{array}$ \\
\hline Gellan Gum-Chitosan & $\begin{array}{l}\text { Ondansetron } \\
\text { Hydrochloride }\end{array}$ & Solid Dosage & Nasal delivery [49] & $\begin{array}{c}\mathrm{t}_{99 \%}=8 \mathrm{~h}(\text { Phosphate Buffer; } \\
\left.\text { pH 7.4; } \mathrm{T}=37^{\circ} \mathrm{C}\right)\end{array}$ \\
\hline Gellan Gum-Chitosan & Curcumin & Nanogel & Intra-tumoral [54] & $\begin{array}{c}\mathrm{t}_{\sim 94 \%}=20 \mathrm{~h} \\
\text { (Phosphate Buffer; } \mathrm{pH} 7.4 ; \\
\mathrm{T}=37^{\circ} \mathrm{C} \text { ) }\end{array}$ \\
\hline Xanthan Gum-Chitosan & \multirow{2}{*}{$\begin{array}{l}\text { Chlorhexidine } \\
\text { (CHX) }\end{array}$} & \multirow{2}{*}{ Hydrogel } & \multirow{2}{*}{ Topical Delivery [53] } & $\begin{array}{c}\mathrm{t}_{\sim 1772(\mu \mathrm{g} / \mathrm{mL})}=168 \mathrm{~h} \\
\text { (Phosphate Buffer; } \mathrm{pH} 7.4 ; \\
\left.\mathrm{T}=37^{\circ} \mathrm{C}\right)\end{array}$ \\
\hline $\begin{array}{c}\text { Xanthan Gum-Chitosan } \\
\text { @Polyethylene Oxide } \\
\text { (PEO) }\end{array}$ & & & & $\begin{array}{c}\mathrm{t}_{\sim 1103(\mu \mathrm{g} / \mathrm{mL})}=168 \mathrm{~h} \\
\text { (Phosphate Buffer; pH 7.4; } \\
\left.\mathrm{T}=37^{\circ} \mathrm{C}\right)\end{array}$ \\
\hline
\end{tabular}


Table 2. Cont.

\begin{tabular}{|c|c|c|c|c|}
\hline \multicolumn{5}{|c|}{ B Cargo delivery } \\
\hline Gum-Based PEC & Composite & & ier Form & Application \\
\hline $\begin{array}{l}\text { Gum Ghatti } \\
\text { (GG)-Chitosan }\end{array}$ & \multirow[t]{2}{*}{ Paracetamol } & \multirow[t]{2}{*}{ Tablets } & \multirow{2}{*}{$\begin{array}{l}\text { Gastrointestinal } \\
\text { Delivery [56] }\end{array}$} & $\begin{array}{c}\mathrm{t}_{54.93 \%}=6 \mathrm{~h}(0.1 \mathrm{M} \mathrm{HCl} ; \mathrm{pH} \\
\left.1,2 ; \mathrm{T}=37^{\circ} \mathrm{C}\right)\end{array}$ \\
\hline $\begin{array}{l}\text { Xanthan Gum } \\
\text { (XG)-Chitosan }\end{array}$ & & & & $\begin{array}{c}\mathrm{t}_{62.27 \%}=6 \mathrm{~h}(0.1 \mathrm{M} \mathrm{HCl} ; \mathrm{pH} \\
\left.1,2 ; \mathrm{T}=37^{\circ} \mathrm{C}\right)\end{array}$ \\
\hline Gellan Gum-Chitosan & Tamoxifen citrate & Nano capsules & Intra-tumoral [58] & $\begin{array}{c}\mathrm{t}_{77.16 \%}=8 \mathrm{~h}(\text { Phosphate Buffer; } \\
\left.\mathrm{pH} 7.4 ; \mathrm{T}=37^{\circ} \mathrm{C}\right)\end{array}$ \\
\hline $\begin{array}{l}\text { carboxymethyl gum } \\
\text { katira-Chitosan }\end{array}$ & Ofloxacin & Nanoparticles & & $\begin{array}{c}\mathrm{t}_{\sim 45 \%}=2 \mathrm{~h} ; \mathrm{t}_{84.32 \%}=24 \mathrm{~h}(0.1 \\
\mathrm{M} \mathrm{HCl} \text { for } 2 \mathrm{~h} \text { followed with } \\
\text { Phosphate Buffer for } 22 \mathrm{~h} ; \mathrm{pH} \\
1,2 \text { and } 7.4 \text { respectively; } \\
\left.\mathrm{T}=37^{\circ} \mathrm{C}\right)[57]\end{array}$ \\
\hline $\begin{array}{l}\text { Xanthan Gum } \\
\text { (XG)-Chitosan }\end{array}$ & Indometachin & Membranes & Topical Delivery [63] & $\begin{array}{c}\mathrm{t}_{20} \text { (mg drug/mg carrier) }=6 \mathrm{~h} \\
\text { (Phosphate Buffer; } \mathrm{pH} 7.4 ; \\
\mathrm{T}=37^{\circ} \mathrm{C} ; 0.092 \mathrm{~mm} \text { thickness) }\end{array}$ \\
\hline \multirow[t]{2}{*}{ Pectin-Chitosan } & \multirow{3}{*}{ Tenofovir } & \multirow{3}{*}{ Tablets } & \multirow{3}{*}{ Vaginal Delivery [79] } & $\begin{array}{l}\mathrm{t}_{\sim 98 \%}=75 \mathrm{~h} \text { (Simulated } \\
\text { Vaginal Fluid (SVF; pH 4.2; } \\
\left.\qquad \mathrm{T}=37^{\circ} \mathrm{C}\right)\end{array}$ \\
\hline & & & & \\
\hline $\begin{array}{l}\text { Locust Beam } \\
\text { Gum-Chitosan }\end{array}$ & & & & $\begin{array}{l}\mathrm{t}_{\sim 93 \%}=75 \mathrm{~h} \text { (Simulated } \\
\text { Vaginal Fluid (SVF; pH 4.2; } \\
\left.\qquad \mathrm{T}=37^{\circ} \mathrm{C}\right)\end{array}$ \\
\hline $\begin{array}{c}\text { Xanthan gum-Chitosan } \\
\text { (Prepare in Hydrochloric } \\
\text { acid (HCl) solution (pH } \\
5.6)\end{array}$ & \multirow{2}{*}{ Ibuprofen } & \multirow{2}{*}{ Solid Dosage } & \multirow{2}{*}{ Oral Delivery [72] } & $\begin{array}{c}\mathrm{t}_{48 \%}=10 \mathrm{~h}(\mathrm{PEC}: \text { drug } \\
\text { ratio }=1: 1) \\
\mathrm{t}_{50.67 \%}=10 \mathrm{~h}(\mathrm{PEC}: \text { drug } \\
\text { ratio }=1: 2)(\text { Phosphate Buffer; } \\
\left.\mathrm{pH} 7.2 ; \mathrm{T}=37^{\circ} \mathrm{C}\right)\end{array}$ \\
\hline $\begin{array}{l}\text { Xanthan gum-Chitosan } \\
\text { (Prepare in Acetic Acid } \\
\text { (AA) (pH 5.6) }\end{array}$ & & & & $\begin{array}{c}\mathrm{t}_{56.84 \%}=10 \mathrm{~h}(\mathrm{PEC}: \text { drug } \\
\text { ratio }=1: 1) \\
\mathrm{t}_{67.75 \%}=10 \mathrm{~h} \\
(\mathrm{PEC}: \text { drug ratio }=1: 2) \\
\text { (Phosphate Buffer; pH } 7.2 ; \\
\left.\mathrm{T}=37^{\circ} \mathrm{C}\right)\end{array}$ \\
\hline
\end{tabular}

\subsection{Gum-Based PECs for Tissue and Bone Regeneration}

The current development of gum-based PECs as tissue engineering leads to the advancement of scaffolds materials. To date, the foremost challenge of tissue engineering development is that the material should be mechanical and functional mimicry of tissue framework [80]. Sant et al. (2017) have fabricated scaffold containing methacrylate modified Gellan Gum (MeGG) and Chitosan with 1:1 ratio with addition of Arginylglycylaspartic acid (RGD) modification through self-assembly microfluidic approach and photocrosslinking technique [51]. The aligned fibrous in their study have successfully replicated the hierarchical structure of natural collagen fibers. These formed fibrous materials present an excellent environment for cells encapsulation, such as rat fibroblasts, cardiomyocytes, and human mesenchymal stem (hMSCs) with insignificant effect in viability under mild conditions. The RGD also acts as scaffold binding sites for cell adhesion and proliferation of hMSCs. This study also presents the possibility of photocrosslinkable MeGG tuning the physicochemical and mechanical characteristics for broad application of tissue engineering such as bone, skeletal, and cardiac muscle to neural tissue. 
In line with the previous study, other characteristics such as the rate of material disintegration, porosity, interconnecting pore framework, and structural homogeneity also play essential roles in regulating the suitability of scaffold for supporting cell growth. de Oliveira and co-authors (2019) reported the composition of GG/chitosan crucially regulating the hydrophilicity-hydrophobicity and mechanical strength of the material, which further beneficially improves bone interaction mesenchymal stem and GG/CS PECs [64]. Moreover, the optimal ratio of CS/GG (80:20) and CS/GG (60:40) present structural homogeneity and high porosity (ranged from 100-200 $\mu \mathrm{m}$ ), which present as one of the desired features since they can imitate the extracellular matrix framework and functions including acted as support cell migration and proliferation, metabolites transportation and assembly and deposition new ECM substances [64].

Natural gums and nanomaterials (such as $\mathrm{Fe}_{3} \mathrm{O}_{4}$ magnetic nanoparticles (MNPs and Hydroxyapatite (HAPs)) present merits features with addictive characteristics. As reported by Rao and co-authors reported that the hydrophilic properties of Xanthan Gum-Chitosan PECs and the external magnetic field of MNPs create scaffolds with stimulating cellular interaction [60]. The merits properties can enhance the cell adhesion and proliferation of NIH3T3 fibroblasts and refined properties such as rheological and compressive features. Low tensile strength and loading bearing are the main issues for implementing synthetic hydroxyapatite (HAP) implants [81]. Recent advances in nanotechnology have made the fabrication composite of HAP and polyelectrolytes (natural gums and polycations material) possible. The composite possesses biocompatibility improvement and bone integration capability, including osteoinductive and osteoconductive. For instance, Zia et al. (2020) designed a tri-scaffold based on Xanthan Gum-Chitosan composite incorporating HAPs [73]. The utilization of this gum has involved the refinement of physical, mechanical, and biological features of the fabricated scaffold. The synergistic effect of its substances presents higher matrix stiffness, more significant interconnectivity pores, smaller crystallite size, and additional carboxylate groups from XAN, which provide high surface area and favors osteoinduction and protein adsorption. Moreover, the integrated scaffold exhibits a moderate degradation rate and antibacterial properties. In addition, the tri scaffold composite also stimulates the differentiation of MG-63 cells with bone cells which potential of improving the rate and ability of bone regeneration [73].

\subsection{Gum-Based PECs for Drug Delivery}

Gum-based PECs have been developed for various dosage forms, including tablets, gel beads, micro- and nanoparticles, membrane film, and hydrogel, having physiologically responsive carriers due to the swelling ability. The combination of gum and polycation may respond towards physiological environment either by the interaction towards tissue surface (mucoadhesive character) or by modifying the mechanical characteristic (swelling characteristic) through physiological fluid contact (e.g., gastrointestinal tract (GIT), nasal, vaginal, lacrimal, etc.) which effectively modulate the release of the drug. Many modified release formulations have been developed to improve drugs' bioavailability, such as delayed-release, sustained release, site-specific release, and receptor-targeted [82]. In common, controlled drug release was found in the peroral dosage form formulation of gum-based PECs to hinder the mucosal irritation and safeguarding drug throughout the stomach from low $\mathrm{pH}$ release and enzyme degradation as well as maintain delivery towards the specific site (refer to Table 2) [83]. Another common system, sustained drug release efficiency, delivered optimum drug concentration for prolonged-release time to preserve therapeutic drug concentration at the specific site and circumvent therapeutic substances' toxicity and side effects. Several types of gum-based PECs were developed for sustained drug release, several administration routes (depicted in Figure 2) will be covered and defined in the following sections. 


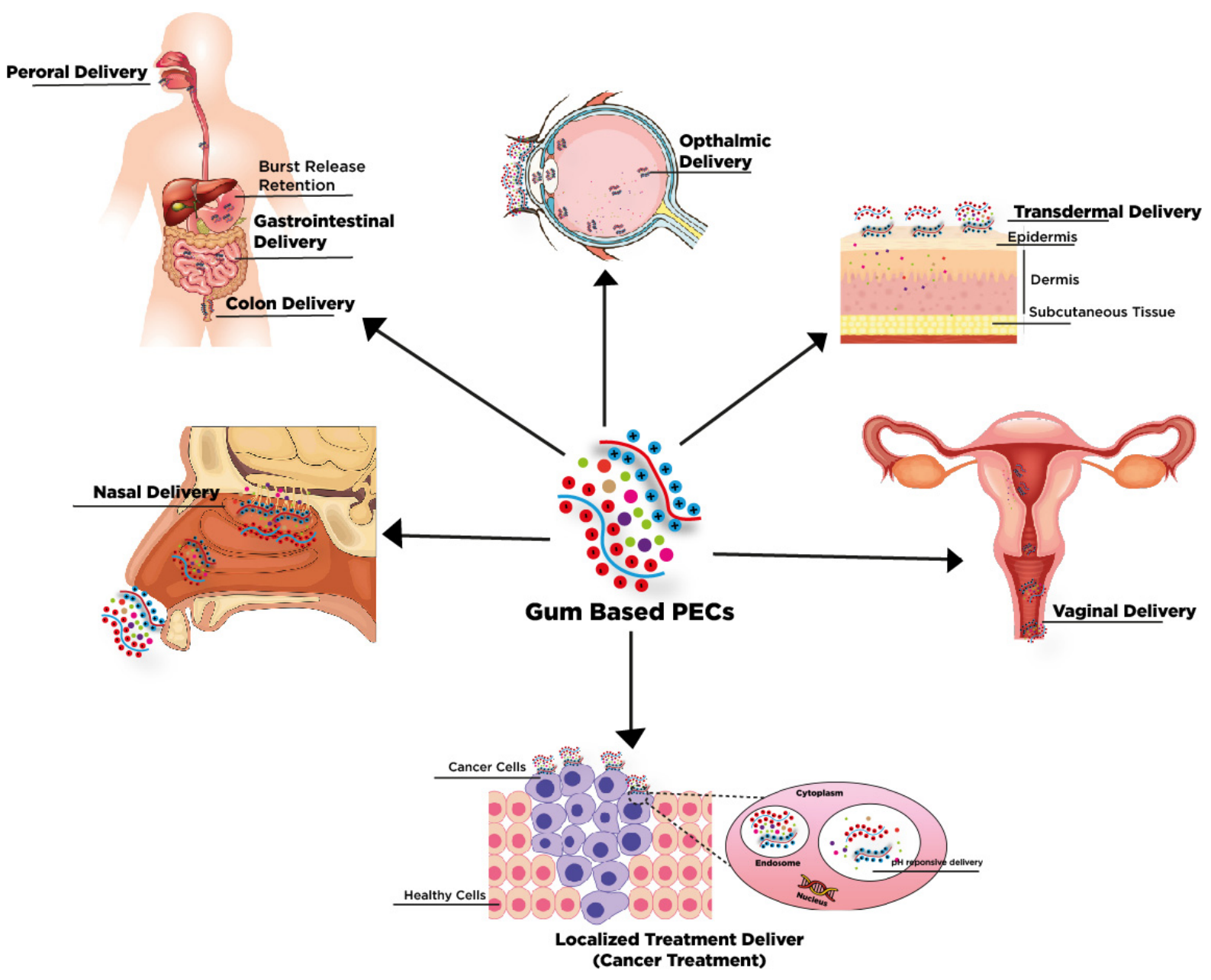

Figure 2. Drug administration route.

\subsubsection{Gum-Based PECs for Peroral Delivery}

Gum-based PECs have been widely developed for the diverse oral delivery formulation, commonly for active pharmaceutical ingredients conveyance towards specific sites of the gastrointestinal system. Despite their biodegradability and nontoxicity, their main characteristics (swelling ability, mucoadhesive, and $\mathrm{pH}$ sensitivity) play a significant role in oral delivery: however, their suitability for oral delivery also depends on the residence time in the gastrointestinal (GI) tract and drug solubility and permeability. The gum-based PECs are acknowledged for their suitability for oral delivery because of the strong interaction between anionic gum (e.g., Xanthan Gum, Pectin, Alginate, Gellan Gum, Tragacanth Gum, and Gum Ghatti) and polycation (e.g., cationic guar gum and Chitosan) under acidic $\mathrm{pH}$ which also suitable for intestinal and colon-specific delivery (refer to Table 2). The presence of several enzymes can improve their biodegradability characteristic (e.g., galactomannanase, pectinolytic enzymes, microflora) [76,84-86]. Furthermore, bacteria combined with chitosan's mucoadhesive characteristic perfectly matched colon-specific drug delivery [87]. Roy et al. (2013) evaluated that the presence of cell-associated enzymes of rat cecal and colonic enzymes effectively degrade the gum Odina-chitosan complexes. They also reported that the strong interaction and elastic mechanical strength modulated the biodegradability of gum-based PECs [38].

Most peroral studies only simulated the drug release based on the simulated gastric and intestinal fluid kinetic release. However, the peroral delivery is more complex in animal or human systems which several factors have to be considered, such as fasting or fed condition, nature of the taken meal, sleep, posture of human corresponding to 
the density, size, and the resistance of dosage form. Therefore, the advanced study must justify gum-based PECs on gastrointestinal delivery through ex vivo and in vivo studies. For specific site delivery, such as intestinal and colon targeting, the mucoadhesive plays a vital role in the drug delivery. Complexes interaction of gum-based PECs provides extended time release of the drug; however, the mucoadhesive characteristic facilitates the localization of drug release at specific sites and dwindles the local irritation.

Manconi et al. (2010) successfully created chitosan-xanthan gum with liposome coating formulation by spray and freeze-drying followed by direct compression, generating tablets for colon-targeted delivery [26]. As a validation, the ex vivo study was carried out on the treated intestinal tissue (e.g., duodenum, jejunum, ileum, and colon) of 24-h fasted Wistar rats (13-week-old) for a mucoadhesive strength test. It was observed that mucoadhesive strength is significantly higher for colon than intestine part for both systems (SD and FD), which in this case, they successfully modified the drug release system to lower residence time in the intestine and extend release time on the colon. Several notes were considered: (1) Contact time was found to be vital for increasing the mucoadhesive strength, and (2) A contrary result to the statement of mucoadhesive strength is in line with the chain flexibility structure and polar functional groups were observed. Spray-dried tablets provide better mucoadhesive than freeze-dried, but their characteristic shows a structured, firm, and stable tablet based on the rheological and swelling studies.

\subsubsection{Gum-Based PECs for Transdermal Delivery}

Similarly, transdermal delivery presents an interesting alternative to oral delivery because the prolonged drug release reduces dosing frequency, retaining plasma levels owing to slower release late. In the situational occasion when oral administration creates serious side effects due to higher peak plasma levels and low drug bioavailability (caused by the narrow therapeutic window, low drug solubility, and first-pass metabolism), transdermal delivery is the best option to deliver the drug [88]. Recently, gum-based PECs were studied to develop a different formulation for drug delivery in wound healing, primarily in the form of membrane and hydrogel microspheres. Several studies have confirmed biocompatibility, biodegradability, moist nature, low toxicity, prolonged drug release, and transparency, essential for wound healing cells. However, Xanthan Gum-Chitosan hydrogel demonstrated the ability to support human dermal fibroblast and deliver antibiotics for local antiseptic for acute or chronic periodontitis treatment.

Meanwhile, a similar study reported that Xanthan Gum-Chitosan hydrogel also improved the incorporation efficiency of the low soluble drug (up to 95\%) and release (20 mg drug/g biopolymer), which slightly closed to therapeutic dosage for active wound healing for skin lesion treatments. In another study, borate modified polyvinyl alcohol and cationic guar-gum poly complexes with nanoparticle/nanocellulose were used as drug carriers. This composite has efficiently improved drug encapsulation efficiency, mechanical strength, thermal stability, skin permeability, and water vapor permeability. That system also presented resistance to microbial growth, supporting the growth of $\mathrm{HaCaT}$ cells (keratinocyte cell line from adult human skin) and negative result in skin irritation test, which potentially affects long-term skin application [52].

\subsubsection{Gum-Based PECs for Other's Delivery Route}

Facile preparation, accurate dosing, and high patience, convenience, and compliance are considered the benefits of ophthalmic drug delivery, which are also desirable for drug routes. Nevertheless, at the same time, poor intraocular bioavailability because of high rates of drug dilution and elimination provoked by lacrimal flow and blinking along with low cornea permeability become the main challenging problem for conventional eye drops.

The advancement of nanoparticles technology leads to the construction of carboxymethyl gum katira-chitosan complexes for ophthalmic drug delivery. The ratio adjustment of carboxymethyl gum katira-chitosan provided through Box-Behnken design provides optimal size particle and drug encapsulation with corneal biocompatibility and 
high corneal permeability. In addition, corneal permeation was also compared with commercial ofloxacin $0.3 \%, w / v$ ophthalmic solution across the porcine cornea. It was observed that slightly higher manifest corneal permeability from nanoparticle formulation [45].

Although not so extensively, gum-based PECs were also implemented for less common delivery routes, including vaginal delivery, ophthalmic and localized drug delivery treatment. Sonje and Mahajan (2016) developed gellan-gum-chitosan with a porous spongelike structure for lyophilized nasal inserts application. This system helps solve several drawbacks of conventional liquid and powder formulation of nasal insert, which have rapid half-life clearance, poor patient compliance, and inefficient drug dosage and delivery. As they combined, GG as ion activated gelling polymer and chitosan with mucoadhesive characteristic, allow several improvements in the dosing accuracy, facile way of administration, water uptake, prolonged drug release time at the site of infection, which have been proved by ex vivo study and in vivo study. Especially the ex vivo study demonstrated the potential nasal delivery in enhancing bioavailability compared to oral delivery based on New Zealand white rabbit as the animal model [49].

Cazorla-Luna et al. (2019) developed a vaginal gel formulation by combining pectin or locust bean gum as a gelling polymer with chitosan as muco-adhesiveness for antiretroviral drug tenofovir. As a result, the strong electrostatic interaction occurs between pectin and chitosan in simulated vaginal fluid, creating the high gelling framework and robustly structured with moderate swelling to prolonged the mucoadhesion residence time and controlled drug release time up to 4 days which the time are suitable to vaginal turnover. In addition, moderate swelling provides the guarantee of therapeutic compliance [79].

Localized cancer treatment using gum-based PECs as the matrix that sustains nanoparticles and provides release control of tamoxifen citrate was reported by [58]. The hybrid system comprising Gellan-Gum and Chitosan complexes incorporated tamoxifen citrate, which was investigated through an in vitro cell viability study of MCF-7 (Breast Cancer Cells). The result showed that composite induces toxic effect by increasing dosage of TMC loaded GG/CS complexes (10-60 $\mathrm{\mu g} / \mathrm{mL}$ ) have increased the death probability of viable cells $(45.67 \%$ to $9.56 \%)$ compared to free drug-TMC suspension ( $53.03 \%$ to $15.54 \%)$. The authors pointed out that the nanosized particle effectively enhances the intracellular uptake capacity of MCF-7 while providing passive targeting and sustained drug delivery. This phenomenon occurred due to the enhancement of permeability and retention effect. The advantages of using nanoparticles were also demonstrated by Mahajan and Patil (2017) by incorporating curcumin into the nano-gel composite of GG/CS complexes. They effectively decreased the $\mathrm{IC}_{50}$ concentration from $13.6 \mathrm{ng} / \mathrm{mL}$ to $9.8 \mathrm{ng} / \mathrm{mL}$ for curcumin suspension and curcumin-loaded nano-gel, respectively [54]. In conclusion, the formulation effectively lowered the astrocytoma-glioblastoma cell line (U373MG) and presented hemocompatibility. In another study, gum-based PECs nanoparticles were also developed for specific target sites for malaria chemotherapy [48] and modified by liposome coating for drug loading and release improvement for pulmonary treatment [33].

\subsubsection{Drug Release Mechanism of Gum-Based PECs}

The drug release mechanism of gum-based PECs was often controlled by (i) diffusion, (ii) degradation or erosion, (iii) solvent, or (iv) stimulus-responsive release [89,90]. In the first case, the drug diffusion was provoked by differences in concentration gradient across the system and carrier. Meanwhile, in the second case, the PECs matrix undergoes degradation simultaneously as time goes by. The PECs matrix was commonly eroded from the surface to the center, which causes the rate of degradation to be higher than solvent or drug diffusion in/out to the matrix. For the third case, the solvent transport towards the drug delivery system has influenced the carrier to present various drug delivery behavior. Osmotic and swelling controlled release are the main types of solvent controlled release. Osmotic controlled-release occurs when water flows towards the center of the carrier with high drug concentration, passing through the permeable matrix driven by convection and osmotic pumping. In a different system, the swelling controlled mechanism is mainly 
constructed by a matrix with a three-dimensional crosslinked network structure (e.g., hydrogel) in which the behavior of drug release is controlled by the mesh size and its solgel characteristics. In the last case, the matrix may have stimuli-responsive characteristics that the drug release behavior induced by external stimulus, including temperature, $\mathrm{pH}$, ionic strength, ultrasound, electricity, magnetic fields, etc. gum-based PECs were advanced for target-specific drug delivery, especially cancer, due to their possibility of localization stimulation. The mechanism is schematically presented in Figure 3.

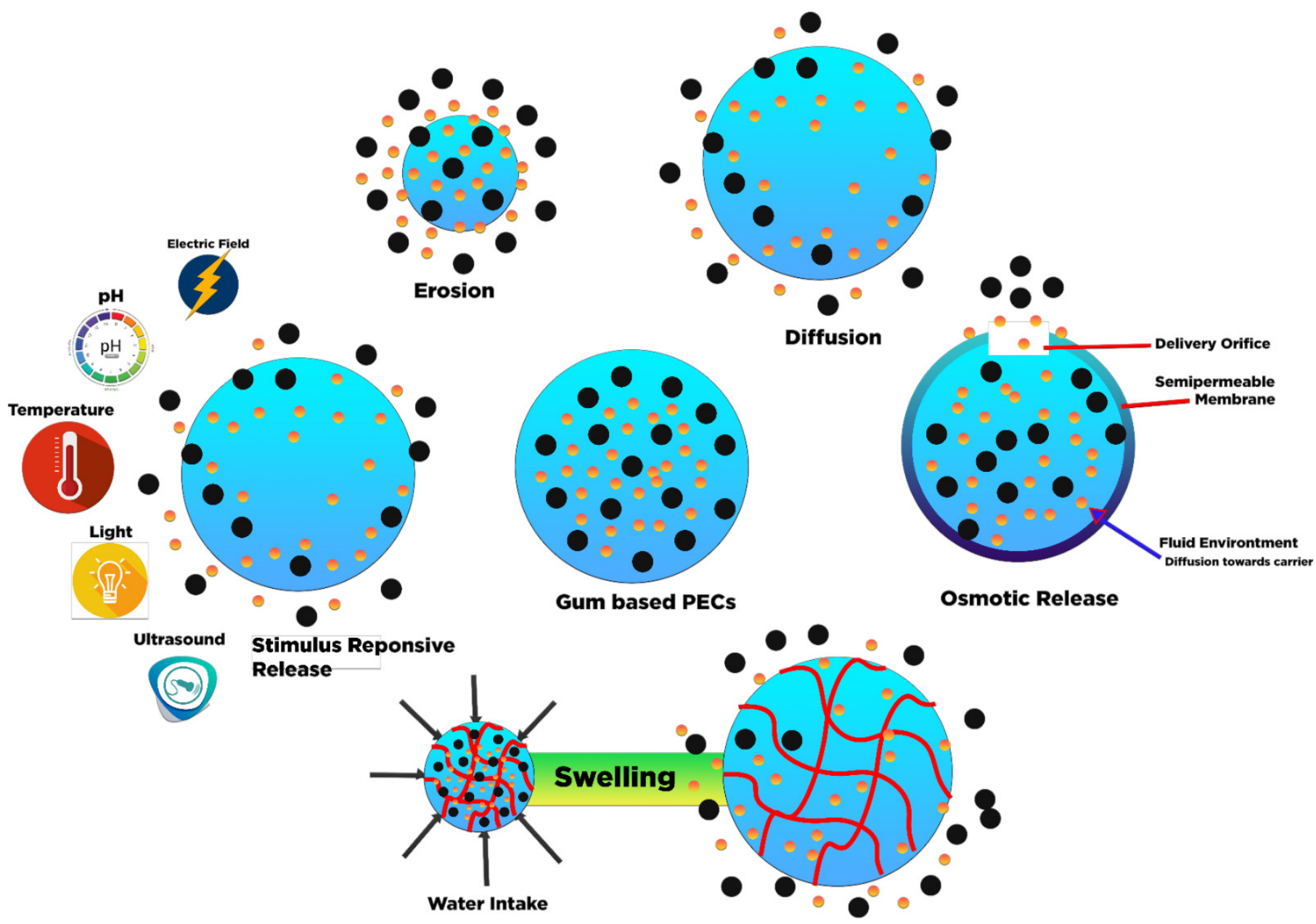

Figure 3. Schematic of drug release mechanism.

The best way to determine the release rate and drug release profile is to compare the experimental findings with several iterative models. Mainly, the model prediction has successfully enlightened the drug release path and functional for drug release optimization. Different models were utilized for finding the suitable mechanism for specific types of carriers, including zero order, first order, Higuchi, Korsmeyer-Peppas, and Peppas-Sahlin (Table 3). The mathematical expression of various models are given as follow (NL and L stand for non-linear and linear equation):

$$
\begin{gathered}
\text { Zero Order Equation : (L) : } Q_{t}=Q_{0}+k_{0} t \\
\text { First Order Equation : (NL) : } Q_{t}=Q_{0} \cdot e^{-k_{1} t} \\
(\mathrm{~L}): \log Q_{t}=\log Q_{0}+\frac{k_{1}}{2.303} t \\
\text { Higuchi Model : }(\mathrm{NL})=Q_{t}=\sqrt{D\left(2 C-C_{s}\right) C_{t}}
\end{gathered}
$$




$$
\begin{gathered}
\text { Simplified Higuchi : (L) : } Q_{t}=k_{H} \sqrt{t} \\
\text { Korsmeyer-Peppas : (NL) : } \frac{M_{t}}{M_{0}}=k_{k p} t^{n} \\
(\mathrm{~L}): \log \left(\frac{M_{t}}{M_{0}}\right)=\log k_{k p}+n \log t \\
\text { Peppas-Sahlin : (NL) : } \frac{M_{t}}{M_{0}}=k_{d} t^{m}+k_{r} t^{2 m}
\end{gathered}
$$

where $Q_{t}$ represents the amount of drug released during the time $t, Q_{0}$ is the initial amount of drug release. Parameters $K_{0}$ and $k_{1}$ are the zero-order and first-order constants, respectively. In the non-linear Higuchi model, $Q$ is the amount of drug released on time $t$ by area unit, $C$ is the initial amount of drug contained in dosage form, $C_{S}$ is the drug solubility in the matrix medium, and $D$ is the coefficient of diffusion in the matrix medium. In the linear model, $Q_{t}$ and $k_{H}$ represent the drug release amount during the time $t$ and the Higuchi kinetic constant, respectively. In the Korsmeyer Peppas model, $\mathrm{M}_{\mathrm{t}} / \mathrm{M}_{0}$ stands for fractional drug release at time $t$, while $K_{k p}$ is the specifics constant for each structural modification and geometrical characteristic of the system (also defined as constant release rate). Parameter $n$ is the release exponent (correspond to the mechanism of drug release)

\begin{tabular}{|c|c|c|c|}
\hline Gum-Based PECs & Drug Model & Carrier Form & Suitable Model \\
\hline $\begin{array}{l}\text { Xanthan Gum-Chitosan } \\
\text { (Spray Dried)/Liposomes }\end{array}$ & \multirow[t]{2}{*}{ C-phycocyanin } & \multirow[t]{2}{*}{$\begin{array}{l}\text { Hydrogel } \\
\text { Tablets [26] }\end{array}$} & \multirow[t]{2}{*}{$\begin{array}{l}\text { Korsmeyer Peppas }(\mathrm{n}<0.45) \\
\quad \text { (Fickian diffusion) }\end{array}$} \\
\hline $\begin{array}{l}\text { Xanthan Gum-Chitosan } \\
\text { (Freeze Dried)/Liposomes }\end{array}$ & & & \\
\hline Gum karaya-chitosan & Diclofenac Sodium & Tablets [31] & $\begin{array}{c}\text { First Order Kinetics } \\
\text { (Simultaneous diffusion and } \\
\text { erosion mechanism) }\end{array}$ \\
\hline $\begin{array}{l}\text { Carboxymethyl gum } \\
\text { kondagogu-chitosan }\end{array}$ & Ofloxacin & Nanoparticles [35] & $\begin{array}{c}\text { Higuchi } \\
\text { (Diffusion controlled Release) }\end{array}$ \\
\hline Xanthan gum-Chitosan & Pediococcus acidilactici cells & Hydrogel microcapsules [39] & $\begin{array}{c}\text { Korsmeyer Peppas } \\
(\mathrm{n}>0.85 \text {-Super II transport } \\
\text { mechanism) } \\
\text { (Chain relaxation } \\
\text { (mobility)-governed mechanism) }\end{array}$ \\
\hline \multirow{4}{*}{ Xanthan Gum-Chitosan } & \multirow{2}{*}{ Theophylline (Th) } & \multirow{4}{*}{ Tablet [40] } & $\begin{array}{c}\text { Korsmeyer Peppas } \\
(0.45<\mathrm{n}<0.89 \text {-anomalous or } \\
\text { non-Fickian release })\end{array}$ \\
\hline & & & $\begin{array}{l}\text { Pepper and Sahlin ( } 4 \text { h-polymer } \\
\text { relaxation or polymer erosion; } 12 \\
\text { h-diffusional release mechanism) }\end{array}$ \\
\hline & \multirow[t]{2}{*}{ Metoprolol succinate } & & $\begin{array}{c}\text { Korsmeyer Peppas } \\
(0.45<\mathrm{n}<0.89 \text {-anomalous or } \\
\text { non-Fickian release })\end{array}$ \\
\hline & & & $\begin{array}{c}\text { Pepper and Sahlin }(2-12 \text { h } \\
\text { diffusional release mechanism) }\end{array}$ \\
\hline $\begin{array}{l}\text { Carboxymethyl gum } \\
\text { katira-Chitosan }\end{array}$ & Ofloxacin & Nanoparticles [45] & $\begin{array}{c}\text { Higuchi } \\
\text { (Diffusional governed } \\
\text { mechanism) }\end{array}$ \\
\hline Gellan Gum-Chitosan & $\begin{array}{l}\text { Ondasetron } \\
\text { Hydrochloride }\end{array}$ & Solid Dosage [49] & $\begin{array}{c}\text { Korsmeyer Peppas } \\
(0.5<\mathrm{n}<1 \text {-anomalous } \\
\text { (non-Fickian) transport) }\end{array}$ \\
\hline
\end{tabular}
as a function of time $t$. Parameters $k_{d}$ and $k_{r}$ in the Pepper and Sahlin model stand for the constant release rate of diffusion and polymer relaxation.

Table 3. Summary of mathematical drug release model gum-based PECs. 
Table 3. Cont.

\begin{tabular}{|c|c|c|c|}
\hline Gum-Based PECs & Drug Model & Carrier Form & Suitable Model \\
\hline $\begin{array}{c}\text { Rhamnogalacturonoglycan } \\
\text { (Rh)-Chitosan (low molecular } \\
\text { weight) } \\
\text { (Mixing charge ratio } \mathrm{n}^{+} / \mathrm{n}^{-} 5 \text { ) }\end{array}$ & \multirow{2}{*}{ Chloroquine } & \multirow{2}{*}{ Nanoparticles [48] } & \multirow[t]{2}{*}{$\begin{array}{c}\text { Korsmeyer Peppas }(\mathrm{n}>0.89) \\
\text { Super case-II transport } \\
\text { of diffusion }\end{array}$} \\
\hline $\begin{array}{c}\text { Rhamnogalacturonoglycan } \\
\text { (Rh)-Chitosan (low molecular } \\
\text { weight) (mixing charge ratio } \\
\mathrm{n}^{+} / \mathrm{n}^{-} 0.1 \text { ) }\end{array}$ & & & \\
\hline Gellan Gum-Chitosan & Curcumin & Nanogel [54] & $\begin{array}{c}\text { Korsmeyer Peppas } \\
(0.5<\mathrm{n}<1 \text {-anomalous } \\
\text { (non-Fickian) transport) }\end{array}$ \\
\hline Gum Ghatti-Chitosan & Paracetamol & Tablets [56] & $\begin{array}{l}\text { Zero Order Equation (drug } \\
\text { release independent to } \\
\text { paracetamol concentration) }\end{array}$ \\
\hline Xanthan Gum-Chitosan & Chlorhexidine (CHX) & Hydrogel Microspheres [53] & $\begin{array}{c}\text { Korsmeyer Peppas } \\
(0.45<\mathrm{n}<0.89 \text {-anomalous or } \\
\text { non-Fickian release })\end{array}$ \\
\hline \multirow{2}{*}{$\begin{array}{l}\text { Xanthan Gum-Chitosan } \\
\text { (prepared in Hydrochloric } \\
\text { acid ( } \mathrm{HCl} \text { ) solution (pH 5.6) }\end{array}$} & $\begin{array}{c}\text { Ibuprofen } \\
\text { (mass ratio of gum-based } \\
\text { PECs: Drug }(1: 1) \text { ) }\end{array}$ & \multirow{4}{*}{ Hard capsules [72] } & \multirow{4}{*}{$\begin{array}{l}\text { Korsmeyer Peppas } \\
(0.5<\mathrm{n}<1 \text {-anomalous } \\
\text { (non-Fickian) transport) }\end{array}$} \\
\hline & $\begin{array}{c}\text { Ibuprofen } \\
\text { (mass ratio of gum-based } \\
\text { PECs: Drug }(1: 2))\end{array}$ & & \\
\hline \multirow{2}{*}{$\begin{array}{c}\text { Xanthan Gum-Chitosan } \\
\text { (prepared in Acetic Acid (AA) } \\
(\mathrm{pH} \mathrm{5.6)}\end{array}$} & $\begin{array}{c}\text { Ibuprofen } \\
\text { (mass ratio of gum-based } \\
\text { PECs: Drug }(1: 1) \text { ) }\end{array}$ & & \\
\hline & $\begin{array}{c}\text { Ibuprofen } \\
\text { (mass ratio of gum-based } \\
\text { PECs: Drug }(1: 2) \text { ) }\end{array}$ & & \\
\hline
\end{tabular}

The zero-order kinetics describes the drug release as time-dependent, and the process takes place at a constant rate independent of drug concentration while the first-order kinetics present contrarily. Both release model has distinctive release profile which the first-order release often represents the initial burst release effect while zero-order releases successfully predicted a sustained or slowed drug release profile. For instance, Lal et al. (2017) successfully construct PECs based on in situ formation through the combination of chitosan and xanthan gum, gum ghatti as polycation, and polyanion, respectively. A sustained and slowed drug release was observed in simulated gastric fluid $(\mathrm{pH} 1.2, \mathrm{HCl}$ $0.1 \mathrm{M})$ [56]. In a different formulation, Lankalapalli and Kolapalli (2012) reported the drug release profile in gum karaya-chitosan PECs were fitted in the first drug release model with over $90-99 \%$ of release in 6-12 h under phosphate buffer simulated fluid ( $\mathrm{pH}$ 7.4). The disintegration of tablets causes the rapid release during dissolution, which causes the failure of matrix gel network formation in the compressed PECs, leading to less cohesiveness of swollen matrix. As observed, the $\mathrm{pH}$ release medium is one of the main aspects of altering the release drug profile, which correlates with the gelling and swelling ability of gum-based PECs [31].

Higuchi presents the theoretical mathematical models of the release of drugs from various matrix systems. The developed mathematical model is related to actively dispersed particles in the homogenous matrix. Several factors such as lipophilic diffusion, planar matrix, and homogenous system are considered in the Higuchi model [91]. Higuchi 
model can be simplified (Eq. 4) through several assumptions: (1) Higher initial drug concentration contained in the matrix compared to the drug solubility; (2) Unidirectional diffusion owing to negligible edge effect; (3) The molecular drug size must be lower than the dosage form thickness; (4) drug diffusivity constant; (5) Negligible swelling or matrix dissolution; (6) Achieving perfect sink condition in the release environment [92]. The simplified Higuchi model representing a linear function related to the drug's concentration is proportional to the square root of time. In most drug release profiles in/on gum-based PECs, the Higuchi model cannot describe the release data well since their structures have the swelling characteristic. However, on some occasions, the Higuchi model could also describe the release of drugs from PECs, as reported by [35,45].

A semi-empirical model named power law was developed by Korsmeyer et al. (1983) and Ritger and Peppas (1987). This power-law model helps analyze the unknown release mechanism or more than one drug release phenomenon (Equations (6) and (7)) $[90,93,94]$. The utilization of this method must comply with the assumptions: (1) One direction of drug release; (2) width and thickness ratio $\leq 1: 10$ [95]. The estimated " $n$ " value determines the types of release mechanisms that govern the drug release profile. For easy reference, the classification of interpretation of $\mathrm{n}$ in different geometrical systems summarized by Bruschi (2015) is given in Table 4.

Table 4. The effect of different carrier geometries on the n-value of the Korsmeyer-Peppas model (adapted from [96]).

\begin{tabular}{cccc}
\hline $\begin{array}{c}\text { Model of Drug } \\
\text { Release Mechanism }\end{array}$ & $\begin{array}{c}\text { Geometrical Shape } \\
\text { of Drug Carrier }\end{array}$ & $\begin{array}{c}\text { Value of Exponential } \\
\mathbf{n} \text { Release }\end{array}$ & $\begin{array}{c}\text { Function of } \mathbf{n} \text { in Terms } \\
\text { of Time Variable }\end{array}$ \\
\hline \multirow{2}{*}{ Fickian Diffusion } & Planar (Thin Films) & 0.5 & $\mathrm{t}^{0.5}$ \\
\cline { 2 - 4 } & Cylinders & 0.45 & $\mathrm{t}^{0.45}$ \\
\cline { 2 - 4 } $\begin{array}{c}\text { Anomalous } \\
\text { Transport }\end{array}$ & Planar (Thin Films) & $0.5<\mathrm{n}<1.0$ & $\mathrm{t}^{0.43}$ \\
\cline { 2 - 4 } & Cylinders & $0.45<\mathrm{n}<0.89$ & $\mathrm{t}^{0.5<\mathrm{n}<1.0}$ \\
\cline { 2 - 4 } \begin{tabular}{c} 
Case I Transport \\
\cline { 2 - 4 }
\end{tabular} & Sphere & $0.43<\mathrm{n}<0.85$ & $\mathrm{t}^{0.45<\mathrm{n}<0.89}$ \\
\cline { 2 - 4 } & Cylinders & 1 & $\mathrm{t}^{0.43<\mathrm{n}<0.85}$ \\
\hline \multirow{2}{*}{$\begin{array}{c}\text { Supercase II } \\
\text { Transport }\end{array}$} & Sphere & 0.89 & $\mathrm{t}^{1}$ \\
\cline { 2 - 4 } & Planar (Thin Films) & $\mathrm{n}>1$ & $\mathrm{t}^{0.85}$ \\
\cline { 2 - 4 } & Cylinders & $\mathrm{n}>0.89$ & $\mathrm{t}^{\mathrm{n}>1}$ \\
\hline
\end{tabular}

Korsmeyer-Peppas have successfully defined the mechanism of several gum-based PECs release systems which suitable in Fickian diffusion (case I) [26], anomalous transport $[40,49,53,72]$, a super-II transport mechanism [39,48]. In the Fickian diffusion, drug release was governed by the diffusion mechanism since the solvent transport rate or diffusion rate is higher than the polymer chain relaxation. Meanwhile, the release mechanism correlated anomalous transport when the velocity of solvent diffusion and polymer chain relaxation exhibited similar magnitude. For the super-II transport mechanism, the solvent diffusion of velocity is significantly higher than Fickian diffusion, accelerating solvent diffusion penetration [97]. It is recommended to use the release curve's portion data until the point reaches $\mathrm{M}_{t} / \mathrm{M}_{0}<0.6$ to provide the best solution of $n$ value.

Peppas and Sahlin develop a model to determine the two contribution mechanisms of diffusional and relaxational in the anomalous drug release process [98]. As present in Equation (8), the coefficient of " $\mathrm{m}$ " stands for purely Fickian diffusion exponent for any geometrical shape for various controlled release systems related to coefficient $n$ of power 
flaw for any shapes, including films cylinder and spheres. In this case, the contribution of the relaxation mechanism is negligible since the functional of $\mathrm{t}^{\mathrm{m}}$ is expressed as the diffusional mechanism, while the relaxation mechanism is presented as a function of $\mathrm{t}^{2 \mathrm{~m}}$. The fraction released $\left(\mathrm{M}_{\mathrm{t}} / \mathrm{M}_{0}\right)$ at time $t$ can be investigated by comparing different models (Korsmeyer-Peppas and Peppas-Sahlin) to justify which mechanism contributes to the release system.

Li et al. (2014) studied the influence of the drug release mechanism of theophylline (slightly soluble) and metoprolol succinate (free soluble) as model drugs in chitosananionic gum-based tablet with SGF followed by SIF as the release medium. Based on the Korsmeyer-Peppas model, the CS-XG system for both drugs presents coupled Fickian diffusion-polymer relaxation mechanisms or Fickian diffusion-erosion $\mathrm{m}$ as a controlled mechanism [40]. For the initial four $h$, the theophylline release mechanism was governed by polymer relaxation or polymer erosion, while metoprolol succinate (free soluble) release was controlled by diffusion and polymer swelling. In the equilibrium stage (12 h), the theophylline release profiles were mainly controlled by diffusional drug transport since the swelling and erosion rate reach equilibrium after $12 \mathrm{~h}$. Meanwhile, the tablet matrix maintains the diffusional release controlled for metoprolol succinate since the release profile was affected by the large concentration gradient in the swelling matrix due to the solubility features of drugs. It can be concluded that anionic polymers and solubility of the characteristic of the drug are the keys to modulation drug release [40].

Not only to determine the mechanism, but the studies mentioned above also present that these modeling systems help evaluate the effect of several aspects such as shape, size, molecular weight, PECs composition, types of drug, etc. Shao et al. (2015) investigated the drug release behavior from tablet matrix-based chitosan as polycation and various polyanionic polymers. It was found that the strength and permeability of PECs on the tablet's surface could be modulated by changing the anionic of gum. In vitro drug release in simulated gastric fluid revealed the combination of chitosan and xanthan gum provides sustained-release rate up to $24 \mathrm{~h}$ for highly soluble drug (sodium valproate and valproic acid mixture) with erosion and swelling controlled mechanism [43]. In addition, it was also observed that changing the ratio of xanthan gum and chitosan and modulating the molecular weight of chitosan unaffected the rate of drug release. Based on the previous study, the presence of PECs-film on the tablet's surface hindered the matrix erosion and swelling, which further prolonged drug release and changed the anionic gums, which provide different gel strength, modulating the erosion capacity of the tablet [40].

The selection of optimal acid preparation of gum-based PECs and initial $\mathrm{pH}$ value is crucial in modulating the release rate and mechanism of the drug from the solid carrier. As presented by Ćirić et al. (2020), with the increasing $\mathrm{pH}$ of acetic acid and $\mathrm{HCl}$, the strength of the solid drug's physical (ionic, hydrogen bonds) interactions decreased, increasing the swelling capacity and hindrance the ibuprofen release and dissolution in phosphate buffer. The authors notified that the alteration in the release rate of ibuprofen corresponded to the different thixotropy characteristics of each type of tablet after rehydration in phosphate buffer [72].

In nanoparticles, the carrier's size is considered the priority of carrier features and drug encapsulation efficiency and release. Minkal et al. (2018) reported the effect of carboxymethyl gum Katira and chitosan concentration on entrapment efficiency and nanoparticle size prepared by the coacervation method. An increase in chitosan concentration and a decrease in the viscosity of CMGK create the smallest nanoparticle size with high entrapment efficiency [57]. Based on the in vitro release study, the carriers were prolonged drug release up to $24 \mathrm{~h}$ with $50 \%$ release. The drug release could be described by the Higuchi model (diffusion governed mechanism). A similar result was also demonstrated by Kumar and Ahuja (2013). In another study, Magalhães Jr. et al. (2016) reported that the molar ratio of positive to negative charges, mixing order of polyelectrolytes, and total polymer concentration affect the particle size of gum-based PECs nanoparticle (chitosan 
and rhamnogalacturonoglycan) [48]. Meanwhile, the charge ratio of PECs was observed to control the release rate of chloroquine for up to 12 days.

\section{Future Perspective}

In recent decades, the number of publications on gum-based PECs for biomedical engineering applications has risen, particularly for drug delivery, tissue and bone regeneration applications. The growing number of papers on the use of Gum PECs is a clear indicator of the material's possible future applications (as indicated in Figure 4). Several reviews and research papers have evaluated the phenomenon of polyelectrolyte complexation between polymers of opposite charge leads to the creation of polymeric carriers which capable of regulating the initial burst as well as the following sustained release of loaded from carrier forms. This might be owing to the high order degree and crystal-like compact structures of synthesized polymeric carriers [56]. Gum hydrocolloids and their modification have exhibited tremendous promise as one of the polyanionic sources in drug carrier formulation. Despite their biodegradability and biocompatibility, their opposite charged partner also plays a significant role such as chitosan in ameliorating the mucoadhesive characteristics.

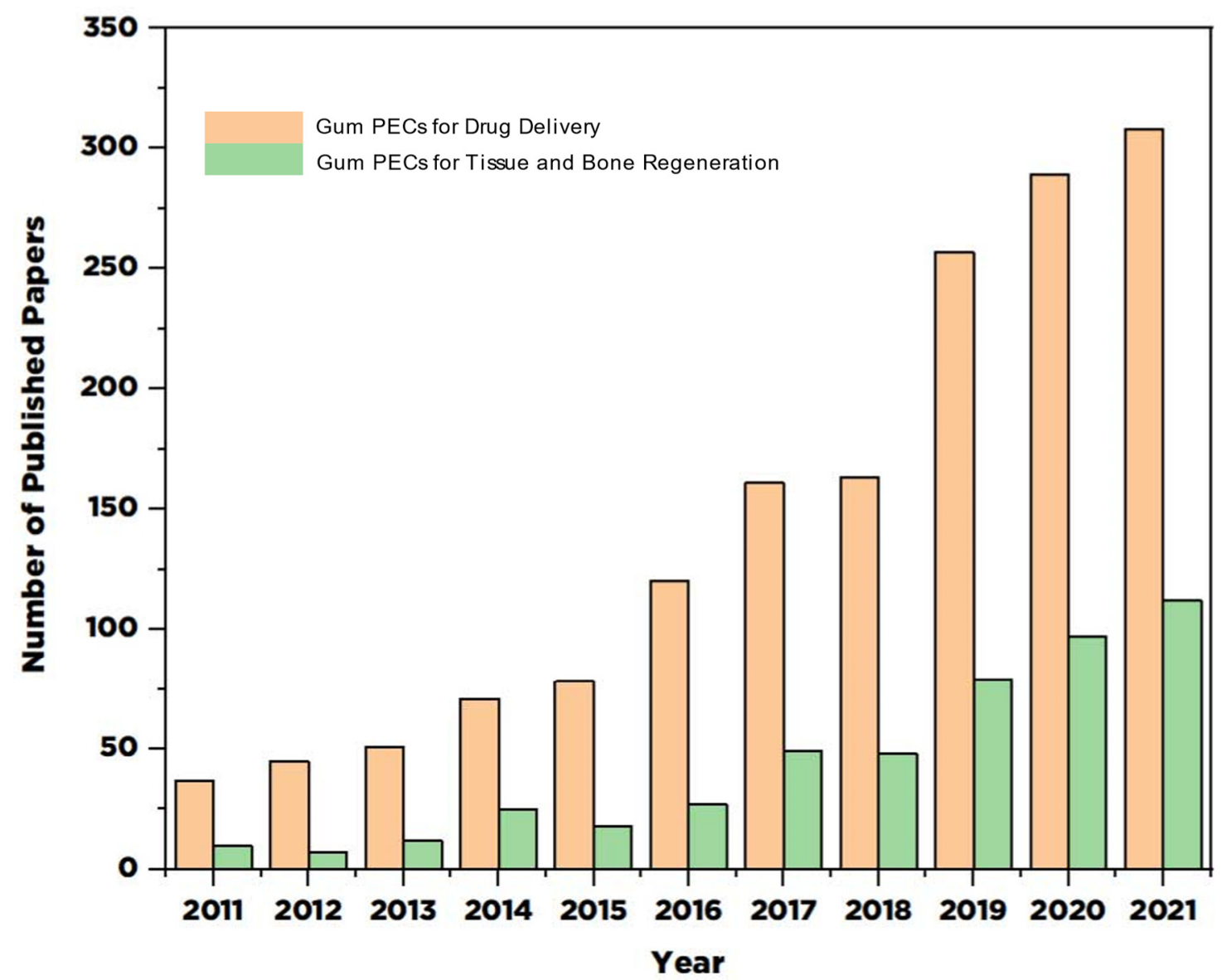

Figure 4. The number of publications in the field of gum-based PECs for drug delivery, tissue and bone regeneration indexed by Scopus from 2011 until recent (24 August 2021). Data analysis was evaluated on Scopus using the keywords: Gum Polyelectrolytes for " $\mathrm{x}$ " ( $\mathrm{x}$ stated as drug delivery, tissue engineering and bone regeneration).

Meanwhile, the ongoing research in scaffold development based on gum PECs were concerned as prospective material since the composites present remarkable result in bone, tissue, and cell regeneration results. The versatility of gum and polycationic selection have paved the way for other advanced material topographical, morphological, and biological excellent features. Nevertheless, further study is required to exploit the potential characteristics of natural gum polysaccharides, as well as their prospective utilization in 
tissue engineering and drug delivery. Researchers should pursue this as an active field of research and conduct further in vivo experiments to back up and reinforce the present findings. In particular, most reviewed studies of gum-based PECs for drug delivery excluded in vivo experiments which regrettably, since the human body has a complex digestion system [99]. Several materials such as 1D carbon nanotubes/2D nanomaterials can be potential candidates as additional material for gum PECs composite owing to their interesting features such as high mechanical characteristic which advantageous to refine the biological and scaffolds mechanical characteristics while also ameliorate the disadvantages of both materials [100,101]. With the sophistication of nanotechnology, it is highly expected to develop economically and non-toxic scaffolds and carriers in the near future through various natural gums and inorganic and organic substances blending.

\section{Conclusions}

Natural gums are widely applied in food formulation and pharmaceutical applications. Functionalization with other polymers is usually conducted to enhance their capability in various applications. The combination of gums with other natural polymers and chitosan to form polyelectrolyte complexes (PEC) are widely studied. Gum hydrocolloid polyelectrolyte complexes (PECs) have potential application in drug delivery systems. The $\mathrm{pH}$ and the ratio of polymers strongly affect the formation of PECs. The mechanism of PECs formation is based on the electrostatic interaction of two oppositely charged polymers. The ratio of polyanion and polycation also influence the particle size and mechanical properties of PECs. Besides being used for the diverse oral delivery formulation, gum-based PECs were also widely developed for peroral drug delivery, transdermal delivery, ophthalmic drug delivery, vaginal delivery, and localized drug delivery treatment. The combination of natural gums with other nanoparticles has a significant challenge in biomedical applications and tissue engineering. Several characteristics such as rate of material disintegration, porosity, interconnecting pore framework, and structural homogeneity are still a challenge for using PECs as a scaffold for supporting cell growth.

Author Contributions: Conceptualization, data curation, writing-original draft preparation by J.N.P.; writing — original draft by V.B.L.; resources F.E.S.; formal analysis M.Y. and S.P.S.; writingreview and editing I.G.W. and S.I.; supervision, funding acquisition S.I. All authors have read and agreed to the published version of the manuscript.

Funding: Directorate of Research and Community Service, Deputy for Strengthening Research and Development, Ministry of Research and Technology/National Research and Innovation Agency, Number: 150D/WM01.5/N/2021.

Institutional Review Board Statement: Not applicable.

Informed Consent Statement: Not applicable.

Data Availability Statement: Data sharing not applicable.

Conflicts of Interest: The authors declare no conflict of interest.

\section{References}

1. BeMiller, J.N. Polysaccharides. In Carbohydrate Chemistry for Food Scientists; Elsevier: Amsterdam, The Netherlands, 2019; pp. 75-101. ISBN 9780128120699.

2. O'Sullivan, J.J.; O'Mahony, J.A. Food Ingredients. In Reference Module in Food Science; Elsevier: Amsterdam, The Netherlands, 2016; pp. 1-3. ISBN 9780081005965.

3. Williams, P.A.; Phillips, G.O. Introduction to food hydrocolloids. In Handbook of Hydrocolloids; Elsevier: Amsterdam, The Netherlands, 2021; pp. 3-26.

4. Verbeken, D.; Dierckx, S.; Dewettinck, K. Exudate gums: Occurrence, production, and applications. Appl. Microbiol. Biotechnol. 2003, 63, 10-21. [CrossRef] [PubMed]

5. Nussinovitch, A. Hydrocolloids for coatings and adhesives. In Handbook of Hydrocolloids; Elsevier: Amsterdam, The Netherlands, 2009; pp. 760-806. ISBN 9781845695873.

6. Mirhosseini, H.; Amid, B.T. A review study on chemical composition and molecular structure of newly plant gum exudates and seed gums. Food Res. Int. 2012, 46, 387-398. [CrossRef] 
7. Rao, P.S.; Sharma, R.K. Studies on indian plant gums: Composition and graded hydrolysis of gum karaya (Sterculia urens Roxb). Proc. Indian Acad. Sci.-Sect. A 1957, 45, 24-29. [CrossRef]

8. Assaad, E.; Ispas-Szabo, P. Chitosan-based polyelectrolyte complexes as pharmaceutical excipients. In Controlled Drug Delivery; Mateescu, M.A., Ispas-Szabo, P., Assaad, E., Eds.; Elsevier: Amsterdam, The Netherlands, 2015; pp. 127-161.

9. Schlenoff, J.B.; Yang, M.; Digby, Z.A.; Wang, Q. Ion Content of Polyelectrolyte Complex Coacervates and the Donnan Equilibrium. Macromolecules 2019, 52, 9149-9159. [CrossRef]

10. Müller, M. Sizing, Shaping and Pharmaceutical Applications of Polyelectrolyte Complex Nanoparticles. Adv. Polym. Sci. 2014, 256, 197-260. [CrossRef]

11. Kulkarni, A.D.; Vanjari, Y.H.; Sancheti, K.H.; Patel, H.M.; Belgamwar, V.S.; Surana, S.J.; Pardeshi, C.V. Polyelectrolyte complexes: Mechanisms, critical experimental aspects, and applications. Artif. Cells Nanomed. Biotechnol. 2016, 44, 1615-1625. [CrossRef]

12. Buriuli, M.; Verma, D. Polyelectrolyte Complexes (PECs) for Biomedical Applications. In Advances in Biomaterials for Biomedical Applications; Springer: Singapore, 2017; pp. 45-93.

13. Subbotin, A.V.; Semenov, A.N. The Structure of Polyelectrolyte Complex Coacervates and Multilayers. Macromolecules 2021, 54, 1314-1328. [CrossRef]

14. Meka, V.S.; Sing, M.K.G.; Pichika, M.R.; Nali, S.R.; Kolapalli, V.R.M.; Kesharwani, P. A comprehensive review on polyelectrolyte complexes. Drug Discov. Today 2017, 22, 1697-1706. [CrossRef]

15. Martins, A.F.; Piai, J.F.; Schuquel, I.T.A.; Rubira, A.F.; Muniz, E.C. Polyelectrolyte complexes of chitosan/heparin and N,N,Ntrimethyl chitosan/heparin obtained at different $\mathrm{pH}$ : I. Preparation, characterization, and controlled release of heparin. Colloid Polym. Sci. 2011, 289, 1133-1144. [CrossRef]

16. Márquez-Beltrán, C.; Castañeda, L.; Enciso-Aguilar, M.; Paredes-Quijada, G.; Acuña-Campa, H.; Maldonado-Arce, A.; Argillier, J.F. Structure and mechanism formation of polyelectrolyte complex obtained from PSS/PAH system: Effect of molar mixing ratio, base-acid conditions, and ionic strength. Colloid Polym. Sci. 2013, 291, 683-690. [CrossRef]

17. Chen, J.; Heitmann, J.A.; Hubbe, M.A. Dependency of polyelectrolyte complex stoichiometry on the order of addition. 1. Effect of salt concentration during streaming current titrations with strong poly-acid and poly-base. Colloids Surfaces A Physicochem. Eng. Asp. 2003, 223, 215-230. [CrossRef]

18. Logothetidis, S.; Sleiman, A.; Sayers, P.W.; Zeze, D.A.; Mabrook, M.F. Handbook of Flexible Organic Electronics; Elsevier: Amsterdam, The Netherlands, 2015; ISBN 9781782420354.

19. Lounis, F.M.; Chamieh, J.; Gonzalez, P.; Cottet, H.; Leclercq, L. Prediction of Polyelectrolyte Complex Stoichiometry for Highly Hydrophilic Polyelectrolytes. Macromolecules 2016, 49, 3881-3888. [CrossRef]

20. Dragan, E.S.; Mihai, M.; Schwarz, S. Polyelectrolyte complex dispersions with a high colloidal stability controlled by the polyion structure and titrant addition rate. Colloids Surfaces A Physicochem. Eng. Asp. 2006, 290, 213-221. [CrossRef]

21. Tsuchida, E. Formation of Polyelectrolyte Complexes and Their Structures. J. Macromol. Sci. Part A 1994, 31, 1-15. [CrossRef]

22. Dragan, S.; Cristea, M. Polyelectrolyte complexes IV. Interpolyelectrolyte complexes between some polycations with N,Ndimethyl-2-hydroxypropyleneammonium chloride units and poly(sodium styrenesulfonate) in dilute aqueous solution. Polymer 2002, 43, 55-62. [CrossRef]

23. Fu, J.; Fares, H.M.; Schlenoff, J.B. Ion-Pairing Strength in Polyelectrolyte Complexes. Macromolecules 2017, 50, 1066-1074. [CrossRef]

24. Narkar, M.; Sher, P.; Pawar, A. Stomach-specific controlled release gellan beads of acid-soluble drug prepared by ionotropic gelation method. AAPS PharmSciTech 2010, 11, 267-277. [CrossRef]

25. Chen, P.H.; Kuo, T.Y.; Wang, D.M.; Lai, J.Y.; Hsieh, H.J. Use of Chitosan as a Material Stabilizer for Acidic Polysaccharides. In Materials Science Forum; Trans Tech Publications Ltd.: Freienbach, Switzerland, 2010; Volume 638-642, pp. 570-575. [CrossRef]

26. Manconi, M.; Mura, S.; Manca, M.L.; Fadda, A.M.; Dolz, M.; Hernandez, M.J.; Casanovas, A.; Díez-Sales, O. Chitosomes as drug delivery systems for C-phycocyanin: Preparation and characterization. Int. J. Pharm. 2010, 392, 92-100. [CrossRef]

27. Silva, D.A.; Maciel, J.S.; Feitosa, J.P.A.; Paula, H.C.B.; de Paula, R.C.M. Polysaccharide-based nanoparticles formation by polyeletrolyte complexation of carboxymethylated cashew gum and chitosan. J. Mater. Sci. 2010, 45, 5605-5610. [CrossRef]

28. Vasiliu, S.; Bunia, I.; Racovita, S.; Neagu, V. Adsorption of cefotaxime sodium salt on polymer coated ion exchange resin microparticles: Kinetics, equilibrium and thermodynamic studies. Carbohydr. Polym. 2011, 85, 376-387. [CrossRef]

29. Amin, K.A.M.; in het Panhuis, M. Polyelectrolyte complex materials from chitosan and gellan gum. Carbohydr. Polym. 2011, 86, 352-358. [CrossRef]

30. Mat Amin, K.A.; Gilmore, K.J.; Matic, J.; Poon, S.; Walker, M.J.; Wilson, M.R.; in het Panhuis, M. Polyelectrolyte Complex Materials Consisting of Antibacterial and Cell-Supporting Layers. Macromol. Biosci. 2012, 12, 374-382. [CrossRef] [PubMed]

31. Lankalapalli, S.; Kolapalli, R.M. Biopharmaceutical evaluation of diclofenac sodium controlled release tablets prepared from gum karaya-chitosan polyelectrolyte complexes. Drug Dev. Ind. Pharm. 2012, 38, 815-824. [CrossRef] [PubMed]

32. Coutinho, D.F.; Sant, S.; Shakiba, M.; Wang, B.; Gomes, M.E.; Neves, N.M.; Reis, R.L.; Khademhosseini, A. Microfabricated photocrosslinkable polyelectrolyte-complex of chitosan and methacrylated gellan gum. J. Mater. Chem. 2012, 22, 17262. [CrossRef]

33. Manca, M.L.; Manconi, M.; Valenti, D.; Lai, F.; Loy, G.; Matricardi, P.; Fadda, A.M. Liposomes Coated with Chitosan-Xanthan Gum (Chitosomes) as Potential Carriers for Pulmonary Delivery of Rifampicin. J. Pharm. Sci. 2012, 101, 566-575. [CrossRef]

34. Ferstl, M.; Drechsler, M.; Rachel, R.; Rischer, M.; Engel, J.; Backofen, M.; Goepferich, A. The Impact of Polyelectrolyte Structure on the Shape of Nanoassemblies with Cationic Peptides. J. Pharm. Sci. 2013, 102, 2599-2607. [CrossRef] 
35. Kumar, A.; Ahuja, M. Carboxymethyl gum kondagogu-chitosan polyelectrolyte complex nanoparticles: Preparation and characterization. Int. J. Biol. Macromol. 2013, 62, 80-84. [CrossRef]

36. Ahuja, M.; Kumar, A. Gum ghatti-chitosan polyelectrolyte nanoparticles: Preparation and characterization. Int. J. Biol. Macromol. 2013, 61, 411-415. [CrossRef]

37. Mahammad, S.S.; Chetty, C.M.; Murthy, K.V.R. Studies on Preparation and Characterization of Polyelectrolyte Complex of Gum Kondagogu and Chitosan: pH-Induced Changes in Swelling, Stability and Bound Water Content. Polym. Plast. Technol. Eng. 2013, 52, 30-37. [CrossRef]

38. Roy, P.S.; Samanta, A.; Mukherjee, M.; Roy, B.; Mukherjee, A. Designing Novel pH-Induced Chitosan-Gum Odina Complex Coacervates for Colon Targeting. Ind. Eng. Chem. Res. 2013, 52, 15728-15745. [CrossRef]

39. Argin, S.; Kofinas, P.; Lo, Y.M. The cell release kinetics and the swelling behavior of physically crosslinked xanthan-chitosan hydrogels in simulated gastrointestinal conditions. Food Hydrocoll. 2014, 40, 138-144. [CrossRef]

40. Li, L.; Wang, L.; Li, J.; Jiang, S.; Wang, Y.; Zhang, X.; Ding, J.; Yu, T.; Mao, S. Insights into the mechanisms of chitosan-anionic polymers-based matrix tablets for extended drug release. Int. J. Pharm. 2014, 476, 253-265. [CrossRef]

41. Sandeep, C.; Deb, T.K.; Moin, A.; Shivakumar, H.G. Cationic guar gum polyelectrolyte complex micro particles. J. Young Pharm. 2014, 6, 11-19. [CrossRef]

42. Tsai, R.-Y.; Chen, P.-W.; Kuo, T.-Y.; Lin, C.-M.; Wang, D.-M.; Hsien, T.-Y.; Hsieh, H.-J. Chitosan/pectin/gum Arabic polyelectrolyte complex: Process-dependent appearance, microstructure analysis and its application. Carbohydr. Polym. 2014, 101, 752-759. [CrossRef]

43. Shao, Y.; Li, L.; Gu, X.; Wang, L.; Mao, S. Evaluation of chitosan-anionic polymers based tablets for extended-release of highly water-soluble drugs. Asian J. Pharm. Sci. 2015, 10, 24-30. [CrossRef]

44. da Silva, B.C.; de Oliveira, M.; Ferreira, J.G.L.; Sierakowski, M.R.; Simas-Tosin, F.F.; Orth, E.S.; Riegel-Vidotti, I.C. Polyelectrolyte complexes from gum arabic and gelatin: Optimal complexation $\mathrm{pH}$ as a key parameter to obtain reproducible microcapsules. Food Hydrocoll. 2015, 46, 201-207. [CrossRef]

45. Ahuja, M.; Bhatt, D.C. Carboxymethyl gum katira: Synthesis, characterization and evaluation for nanoparticulate drug delivery. RSC Adv. 2015, 5, 82363-82373. [CrossRef]

46. Sarika, P.R.; Pavithran, A.; James, N.R. Cationized gelatin/gum arabic polyelectrolyte complex: Study of electrostatic interactions. Food Hydrocoll. 2015, 49, 176-182. [CrossRef]

47. Sakloetsakun, D.; Preechagoon, D.; Bernkop-Schnürch, A.; Pongjanyakul, T. Chitosan-gum arabic polyelectrolyte complex films: Physicochemical, mechanical and mucoadhesive properties. Pharm. Dev. Technol. 2016, 21, 590-599. [CrossRef] [PubMed]

48. Magalhães, G.A., Jr.; Moura Neto, E.; Sombra, V.G.; Richter, A.R.; Abreu, C.M.W.S.; Feitosa, J.P.A.; Paula, H.C.B.; Goycoolea, F.M.; de Paula, R.C.M. Chitosan/Sterculia striata polysaccharides nanocomplex as a potential chloroquine drug release device. Int. J. Biol. Macromol. 2016, 88, 244-253. [CrossRef] [PubMed]

49. Sonje, A.G.; Mahajan, H.S. Nasal inserts containing ondansetron hydrochloride based on Chitosan-gellan gum polyelectrolyte complex: In vitro-in vivo studies. Mater. Sci. Eng. C 2016, 64, 329-335. [CrossRef] [PubMed]

50. Hu, Q.; Wang, T.; Zhou, M.; Xue, J.; Luo, Y. Formation of redispersible polyelectrolyte complex nanoparticles from gallic acid-chitosan conjugate and gum arabic. Int. J. Biol. Macromol. 2016, 92, 812-819. [CrossRef] [PubMed]

51. Sant, S.; Coutinho, D.F.; Gaharwar, A.K.; Neves, N.M.; Reis, R.L.; Gomes, M.E.; Khademhosseini, A. Self-Assembled Hydrogel Fiber Bundles from Oppositely Charged Polyelectrolytes Mimic Micro-/Nanoscale Hierarchy of Collagen. Adv. Funct. Mater. 2017, 27, 1606273. [CrossRef] [PubMed]

52. Anirudhan, T.S.; Nair, S.S.; Sekhar, V.C. Deposition of gold-cellulose hybrid nanofiller on a polyelectrolyte membrane constructed using guar gum and poly(vinyl alcohol) for transdermal drug delivery. J. Memb. Sci. 2017, 539, 344-357. [CrossRef]

53. Kim, J.; Hwang, J.; Seo, Y.; Jo, Y.; Son, J.; Choi, J. Engineered chitosan-xanthan gum biopolymers effectively adhere to cells and readily release incorporated antiseptic molecules in a sustained manner. J. Ind. Eng. Chem. 2017, 46, 68-79. [CrossRef]

54. Mahajan, H.S.; Patil, P.P. In situ cross Linked Chitosan-Gellan Gum Polyelectrolyte Complex Based Nanogels Containing Curcumin for Delivery to Cancer Cells. Indian J. Pharm. Educ. Res. 2017, 51, s40-s45. [CrossRef]

55. Huang, G.-Q.; Du, Y.-L.; Xiao, J.-X.; Wang, G.-Y. Effect of coacervation conditions on the viscoelastic properties of N,Ocarboxymethyl chitosan-gum Arabic coacervates. Food Chem. 2017, 228, 236-242. [CrossRef]

56. Lal, N.; Dubey, J.; Gaur, P.; Verma, N.; Verma, A. Chitosan based in situ forming polyelectrolyte complexes: A potential sustained drug delivery polymeric carrier for high dose drugs. Mater. Sci. Eng. C 2017, 79, 491-498. [CrossRef]

57. Ahuja, M.; Bhatt, D.C. Polyelectrolyte complex of carboxymethyl gum katira-chitosan: Preparation and characterization. Int. J. Biol. Macromol. 2018, 106, 1184-1191. [CrossRef]

58. Kathle, P.K.; Gautam, N.; Kesavan, K. Tamoxifen citrate loaded chitosan-gellan nanocapsules for breast cancer therapy: Development, characterisation and in-vitro cell viability study. J. Microencapsul. 2018, 35, 292-300. [CrossRef]

59. Nur, M.; Vasiljevic, T. Insulin Inclusion into a Tragacanth Hydrogel: An Oral Delivery System for Insulin. Materials 2018, 11, 79. [CrossRef] [PubMed]

60. Rao, K.M.; Kumar, A.; Han, S.S. Polysaccharide-based magnetically responsive polyelectrolyte hydrogels for tissue engineering applications. J. Mater. Sci. Technol. 2018, 34, 1371-1377. [CrossRef]

61. Kaur, J.; Kaur, G. Optimization of $\mathrm{pH}$ conditions and characterization of polyelectrolyte complexes between gellan gum and cationic guar gum. Polym. Adv. Technol. 2018, 29, 3035-3048. [CrossRef] 
62. Brar, V.; Kaur, G. Preparation and Characterization of Polyelectrolyte Complexes of Hibiscus esculentus (Okra) Gum and Chitosan. Int. J. Biomater. 2018, 2018, 1-7. [CrossRef]

63. Lopes, S.A.; Veiga, I.G.; Bierhalz, A.C.K.; Pires, A.L.R.; Moraes, Â.M. Physicochemical properties and release behavior of indomethacin-loaded polysaccharide membranes. Int. J. Polym. Mater. Polym. Biomater. 2019, 68, 956-964. [CrossRef]

64. de Oliveira, A.C.; Vilsinski, B.H.; Bonafé, E.G.; Monteiro, J.P.; Kipper, M.J.; Martins, A.F. Chitosan content modulates durability and structural homogeneity of chitosan-gellan gum assemblies. Int. J. Biol. Macromol. 2019, 128, 114-123. [CrossRef]

65. Khoerunisa, A.D.N.; Nugraheni, P.S.; Fahrurrozi, M.; Budhijanto, W. Selection of Polyanions as Complexation Agent in the Formation of Nanochitosan by Polyelectrolyte Complex Method. In Materials Science Forum; Trans Tech Publications Ltd.: Freienbach, Switzerland, 2019; Volume 948, pp. 140-145. [CrossRef]

66. Slavutsky, A.M.; Bertuzzi, M.A. Formulation and characterization of hydrogel based on pectin and brea gum. Int. J. Biol. Macromol. 2019, 123, 784-791. [CrossRef] [PubMed]

67. Maciejewski, B.; Sznitowska, M. Gelatin Films Modified with Acidic and Polyelectrolyte Polymers-Material Selection for Soft Gastroresistant Capsules. Polymers 2019, 11, 338. [CrossRef]

68. Rodríguez-Rodríguez, R.; Espinosa-Andrews, H.; Morales-Hernández, N.; Lobato-Calleros, C.; Vernon-Carter, E.J. Mesquite gum/chitosan insoluble complexes: Relationship between the water state and viscoelastic properties. J. Dispers. Sci. Technol. 2019, 40, 1345-1352. [CrossRef]

69. de Oliveira, L.C.; Barbosa, J.R.; Ribeiro, S.D.C.A.; de Vasconcelos, M.A.M.; de Aguiar, B.A.; da Silva Pereira, G.V.; Albuquerque, G.A.; da Silva, F.N.L.; Crizel, R.L.; Campelo, P.H.; et al. Improvement of the characteristics of fish gelatin-gum arabic through the formation of the polyelectrolyte complex. Carbohydr. Polym. 2019, 223, 115068. [CrossRef]

70. Pereira, V.d.A.; Ribeiro, I.S.; Paula, H.C.B.; de Paula, R.C.M.; Sommer, R.L.; Rodriguez, R.J.S.; Abreu, F.O.M.S. Chitosan-based hydrogel for magnetic particle coating. React. Funct. Polym. 2020, 146, 104431. [CrossRef]

71. de Oliveira, A.C.; Sabino, R.M.; Souza, P.R.; Muniz, E.C.; Popat, K.C.; Kipper, M.J.; Zola, R.S.; Martins, A.F. Chitosan/gellan gum ratio content into blends modulates the scaffolding capacity of hydrogels on bone mesenchymal stem cells. Mater. Sci. Eng. $C$ 2020, 106, 110258. [CrossRef] [PubMed]

72. Ćirić, A.; Medarević, Đ.; Čalija, B.; Dobričić, V.; Mitrić, M.; Djekic, L. Study of chitosan/xanthan gum polyelectrolyte complexes formation, solid state and influence on ibuprofen release kinetics. Int. J. Biol. Macromol. 2020, 148, 942-955. [CrossRef]

73. Zia, I.; Jolly, R.; Mirza, S.; Umar, M.S.; Owais, M.; Shakir, M. Hydroxyapatite Nanoparticles Fortified Xanthan Gum-Chitosan Based Polyelectrolyte Complex Scaffolds for Supporting the Osteo-Friendly Environment. ACS Appl. Bio Mater. 2020, 3, 7133-7146. [CrossRef]

74. da Silva, C.E.P.; de Oliveira, M.A.S.; Simas, F.F.; Riegel-Vidotti, I.C. Physical chemical study of zein and arabinogalactans or glucuronomannans polyelectrolyte complexes and their film-forming properties. Food Hydrocoll. 2020, 100, 105394. [CrossRef]

75. Rana, V.; Rai, P.; Tiwary, A.K.; Singh, R.S.; Kennedy, J.F.; Knill, C.J. Modified gums: Approaches and applications in drug delivery. Carbohydr. Polym. 2011, 83, 1031-1047. [CrossRef]

76. Koyyada, A.; Orsu, P. Natural gum polysaccharides as efficient tissue engineering and drug delivery biopolymers. J. Drug Deliv. Sci. Technol. 2021, 63, 102431. [CrossRef]

77. Nazarzadeh Zare, E.; Makvandi, P.; Tay, F.R. Recent progress in the industrial and biomedical applications of tragacanth gum: A review. Carbohydr. Polym. 2019, 212, 450-467. [CrossRef]

78. Luo, Y.; Wang, Q. Recent development of chitosan-based polyelectrolyte complexes with natural polysaccharides for drug delivery. Int. J. Biol. Macromol. 2014, 64, 353-367. [CrossRef]

79. Cazorla-Luna, R.; Notario-Pérez, F.; Martín-Illana, A.; Ruiz-Caro, R.; Tamayo, A.; Rubio, J.; Veiga, M.D. Chitosan-based mucoadhesive vaginal tablets for controlled release of the anti-HIV drug tenofovir. Pharmaceutics 2019, 11, 20. [CrossRef]

80. Kim, D.; Thangavelu, M.; Cheolui, S.; Kim, H.S.; Choi, M.J.; Song, J.E.; Khang, G. Effect of different concentration of demineralized bone powder with gellan gum porous scaffold for the application of bone tissue regeneration. Int. J. Biol. Macromol. 2019, 134, 749-758. [CrossRef]

81. Bal, Z.; Kaito, T.; Korkusuz, F.; Yoshikawa, H. Bone regeneration with hydroxyapatite-based biomaterials. Emergent Mater. 2020, 3 , 521-544. [CrossRef]

82. Shariatinia, Z. Pharmaceutical applications of natural polysaccharides. In Natural Polysaccharides in Drug Delivery and Biomedical Applications; Elsevier: Amsterdam, The Netherlands, 2019; pp. 15-57. ISBN 9780128170557.

83. Liu, L.; Yao, W.D.; Rao, Y.F.; Lu, X.Y.; Gao, J.Q. pH-responsive carriers for oral drug delivery: Challenges and opportunities of current platforms. Drug Deliv. 2017, 24, 569-581. [CrossRef] [PubMed]

84. Singh, B.N.; Trombetta, L.D.; Kim, K.H. Biodegradation behavior of gellan gum in simulated colonic media. Pharm. Dev. Technol. 2004, 9, 399-407. [CrossRef] [PubMed]

85. Patel, J.; Maji, B.; Moorthy, N.S.H.N.; Maiti, S. Xanthan gum derivatives: Review of synthesis, properties and diverse applications. RSC Adv. 2020, 10, 27103-27136. [CrossRef]

86. Assifaoui, A.; Chambin, O. Pectin as Drug-Release Vehicle. In Pectin: Technological and Physiological Properties; Springer International Publishing: Cham, Germany, 2020; pp. 189-207. ISBN 9783030534202.

87. Samprasit, W.; Opanasopit, P.; Chamsai, B. Mucoadhesive chitosan and thiolated chitosan nanoparticles containing alpha mangostin for possible Colon-targeted delivery. Pharm. Dev. Technol. 2021, 26, 362-372. [CrossRef] [PubMed] 
88. Zhu, J.; Tang, X.; Jia, Y.; Ho, C.T.; Huang, Q. Applications and delivery mechanisms of hyaluronic acid used for topi$\mathrm{cal} /$ transdermal delivery-A review. Int. J. Pharm. 2020, 578, 119127. [CrossRef]

89. Safdar, R.; Omar, A.A.; Arunagiri, A.; Regupathi, I.; Thanabalan, M. Potential of Chitosan and its derivatives for controlled drug release applications-A review. J. Drug Deliv. Sci. Technol. 2019, 49, 642-659. [CrossRef]

90. Peppas, N.A.; Narasimhan, B. Mathematical models in drug delivery: How modeling has shaped the way we design new drug delivery systems. J. Control. Release 2014, 190, 75-81. [CrossRef] [PubMed]

91. Higuchi, T. Mechanism of Sustained- Action Medication. J. Pharm. Sci. 1963, 52, 1145-1149. [CrossRef]

92. Siepmann, J.; Peppas, N.A. Modeling of drug release from delivery systems based on hydroxypropyl methylcellulose (HPMC). Adv. Drug Deliv. Rev. 2012, 64, 163-174. [CrossRef]

93. Korsmeyer, R.W.; Gurny, R.; Doelker, E.; Buri, P.; Peppas, N.A. Mechanisms of solute release from porous hydrophilic polymers. Int. J. Pharm. 1983, 15, 25-35. [CrossRef]

94. Ritger, P.L.; Peppas, N.A. A simple equation for description of solute release I. Fickian and non-fickian release from non-swellable devices in the form of slabs, spheres, cylinders or discs. J. Control. Release 1987, 5, 23-36. [CrossRef]

95. Peppas, N.A. Analysis of Fickian and non-Fickian drug release from polymers. Pharm. Acta Helv. 1985, 60, 110-111. [PubMed]

96. Bruschi, M.L. Mathematical models of drug release. In Strategies to Modify the Drug Release from Pharmaceutical Systems; Bruschi, M.L., Ed.; Elsevier: Amsterdam, The Netherlands, 2015; pp. 63-86. ISBN 978-0-08-100092-2.

97. Klech, C.M.; Simonelli, A.P. Examination of the moving boundaries associated with non-fickian water swelling of glassy gelatin beads: Effect of solution pH. J. Memb. Sci. 1989, 43, 87-101. [CrossRef]

98. Peppas, N.A.; Sahlin, J.J. A simple equation for the description of solute release. III. Coupling of diffusion and relaxation. Int. J. Pharm. 1989, 57, 169-172. [CrossRef]

99. Byrne, J.; Huang, H.-W.; McRae, J.C.; Babaee, S.; Soltani, A.; Becker, S.L.; Traverso, G. Devices for drug delivery in the gastrointestinal tract: A review of systems physically interacting with the mucosa for enhanced delivery. Adv. Drug Deliv. Rev. 2021, 113926. [CrossRef]

100. Gutiérrez-Hernández, J.M.; Escobar-García, D.M.; Escalante, A.; Flores, H.; González, F.J.; Gatenholm, P.; Toriz, G. In vitro evaluation of osteoblastic cells on bacterial cellulose modified with multi-walled carbon nanotubes as scaffold for bone regeneration. Mater. Sci. Eng. C 2017, 75, 445-453. [CrossRef] [PubMed]

101. Zhang, L.; Webster, T.J. Nanotechnology and nanomaterials: Promises for improved tissue regeneration. Nano Today 2009, 4, 66-80. [CrossRef] 